\title{
Essay
}

\section{Categorical Federalism: Jurisdiction, Gender, and the Globe}

\author{
Judith Resnik ${ }^{\dagger}$
}

\section{PLACING POWER}

"The Constitution requires a distinction between what is truly national and what is truly local." 1 These words were used by the Chief Justice of the United States Supreme Court in 2000 to explain why a statute described by Congress as providing a "civil rights remedy" for victims of gender-biased assaults unconstitutionally trenched on lawmaking arenas belonging to the states. Neither the phrase "truly local" nor "truly national" appears in the United States Constitution. Indeed, the Court's reliance on the modifier "truly" suggested that calling something local or national did not suffice to capture the constitutional distinction claimed - that the Violence Against Women Act (VAWA) impermissibly addressed activities definitional of and reserved to state governance.

This Essay considers the mode of analysis for which the phrases "truly national" and "truly local" are touchstones. Categorical federalism is the

$\dagger$ Arthur Liman Professor of Law, Yale Law School. My thanks to Dennis Curtis, Barbara Atwood, Kathy Baker, Naomi Cahn, Mary Clark, Gene Coakley, Anne Dailey, Gráinne de Búrca, Rosa Ehrenreich, Julie Goldscheid, Margaret Groban, Marty Guggenheim, Carolyn Heilbrun, Vicki Jackson, Linda Kerber, Lisa Kloppenberg, Harold Koh, Sylvia Law, David Nachman, Jim Pope, Robert Post, Catherine Powell, Frances Raday, Tanina Rostain, Reva Siegel, Angela Ward, Merle Weiner, Robert Wintemute, and Diane Zimmerman; to Cecily Baskir, Eric Biber, Elizabeth Brundige, Josh Civin, Laura Fernandez, Joe Landau, Deborah Martinez, Tracey Parr, Sarah Russell, and Julie Suk; and to participants in the CUNY Graduate School Conference on Women and Constitutions, in the AALS session, Transcending Boundaries, and in the Yale Faculty Workshop, with whom I have learned a great deal.

1. United States v. Morrison, 529 U.S. 598, 617-18 (2000) (holding unconstitutional the civil rights remedy of the Violence Against Women Act, 42 U.S.C. § 13981 (1994)). 
term I offer for this form of reasoning. Categorical federalism's method first assumes that a particular rule of law regulates a single aspect of human action: Laws are described as about "the family," "crime," or "civil rights" as if laws were univocal and human interaction similarly onedimensional. Second, categorical federalism relies on such identification to locate authority in state or national governments and then uses the identification as if to explain why power to regulate resides within one or another governmental structure. Third, categorical federalism has a presumption of exclusive control-to wit, if it is family law, it belongs only to the states. Categories are thus constructed around two sets of human activities, the subject matter of regulation and the locus of governance, with each assumed to have intelligible boundaries and autonomous spheres.

Categorical federalism has appeal, particularly in a world as full of vivid changes as the one we inhabit. Proponents of categorical federalism argue that its virtue lies in its democracy-enhancing features. The Court's interventions, in the name of federalism, are supposed to engender responsibility on the part of government officials by promoting transparent lines of accountability. Categorical federalism posits and promises clearly delineated allocations of power by suggesting, comfortingly, that these delineations flow "naturally" through the United States's history from a topic to a geographically located government. As federal judges distinguish the "truly local" from the "truly national," they abjure their own responsibility by casting their project as empirical rather than interpretive, a historical exercise aimed at describing and implementing agreements forged in 1789. A resulting cottage industry for law professors is the scouring of texts from 1760 to 1840 to pin down the thoughts of various drafters and Justices.

But the search for meaning from 1789 cannot work because "the federal" had yet to be made. The issue then, ${ }^{2}$ and now, is what meaning and purposes to give to federal and state governments. In a world increasingly conscious that "the local" and "the national" are ideas as well as places, the quaint tidiness of categorical federalism ought to prompt skepticism. In international parlance, "local law" refers to what in the United States is termed "national law." Technology permits easy transgeographic exchanges that diminish the significance of physical boundaries. Transnational organizations promulgate worldwide legal norms, affecting practices within nation-states.

Moreover, national borders are not the only lines that are blurring. Boundaries of role are also shifting, as women and men explore the

2. See, e.g., James Roger Sharp, American Politics IN THE EARLy RePublic (1993) (arguing the basic instability of the country at its inception); DAVID WALDSTREICHER, IN THE MIDST OF PERPETUAL FETES: THE MAKING OF AMERICAN NATIONALISM, 1776-1820 (1997) (examining efforts at inventing civic rituals to form a national identity). 
possibility that their genders offer less instruction on their life opportunities than has been claimed for thousands of years. Gender systems work through assumptions about the intelligibility of the categories of "women" and "men," which in turn depend upon demarcations of "the family" from "the market" and of "the private" from "the public." Currently, violence and money play different roles in the lives of women and men. Women live with threats to their physical safety from men within and outside their households; women's unpaid household labors facilitate men's market capacities. To diminish the categorical coherence of gender requires extricating women from the dominion, both physical and economic, of male-headed households. Efforts to do so are underway worldwide, as longstanding rules of politics (such as who can vote), of entrenched legal and social practices (such as who controls access to women's bodies), of markets (such as what work is remunerated), and even of war (such as whether victors may exercise sexual dominion over enemy civilian women) are all being revisited.

Given this context, categorical federalism ought to be understood as a political claim, advancing an argument that certain forms of human interactions should be governed by a particular locality, be it a nation-state or its subdivisions. Return then to the Chief Justice's locution- "truly national," "truly local" - and reread it to betray anxiety as well as insistence, as an effort to make meaningful a division that is not only elusive but increasingly inaccurate. Categorical federalism's attempt to buffer the states from the nation, and this nation from the globe, is faulty as a method and wrong as an aspiration.

Below, I sketch the empirical case against categorical federalism by showing that the very areas characterized in the VAWA litigation as "Iocal"-family life and criminal law-have long been subjected to federal lawmaking. Decades of federal constitutional family law create substantive rights anchored in the Fourteenth Amendment for parents and children, just as decades of federal legislation-addressing welfare, pension, tax, bankruptcy, and immigration-have defined membership in and relationships within groupings denominated "families" by the national government.

The normative critique of categorical federalism stems from the political injuries caused by equating family life with state law. Categorical federalism is not only fictive but harmful, for it deflects attention from the many political and legal judgments made by the nation's judiciary, executive, and Congress as they regulate the lives of current and former householders. Federal actors ought not to be sheltered from accounting for their work in shaping the meaning of gendered family roles. And just as it cloaks the exercise of national powers from view, categorical federalism also provides a false sense of security from transnational lawmaking. 
United States laws of all kinds are increasingly altered, if not trumped, by practices stemming from quarters physically distant from Washington but not far in forms of space that globalization has come to represent. The United States government needs to develop means of interacting with these laws rather than to assume an ability to remain insular. In the twenty-first century, believing one can mandate the boundaries is seductive but wrong (a lesson all too powerfully brought home as this Essay was in press).

To interrupt the embrace of categorical federalism, I offer another approach, which I term multi-faceted federalism, to highlight alternative ways of reasoning about federated governance and regulation. Categories are endemic, in law as elsewhere, but what fills categories and their contours varies with context. Return to the issue of violence against women: If a man raped a woman and proclaims he did so because he likes to inflict such pain on women, what should law call that action? Should the description vary if the man and woman have been (or are) married instead of strangers? If they were employer and employee? Opponents in a war? Should the legal import vary if the man assaults the woman as she is about to leave the house on her way to school, work, or another shelter? Do understandings of the relevant legal norms shift upon concluding that many men rape women, many husbands beat wives, many employers sexually assault certain kinds of employees, and many soldiers rape women in countries at war? As these questions illustrate, in law, decisions to categorize are purposeful, consequentialist, and situational.

My goal is not to refuse categorization but to introduce other presumptions into federalism discourse-that many categories are intertwined in lawmaking enterprises and that more than one source of legal regulation is likely to apply to any set of behaviors. This legal theory mirrors contemporary research about categorization in cognitive psychology. Criticism of the "classic" view that categories have specified boundaries comes from studies demonstrating that "categories are variable as well as stable," ${ }^{3}$ that people use "differing bases for assessing category membership," that "[w]hat counts as a feature of a category and which features are likely to be important" are influenced by background knowledge, ${ }^{5}$ and that categories have ambiguous boundaries. Multi-faceted

3. Linda B. Smith \& Larissa K. Samuclson, Perceiving and Remembering: Category Stability, Variability and Development, in KNOWLEDGE, CONCEPTS AND CATEGORIES 161, 170 (Koen Lamberts \& David Shanks eds., 1997) (reporting that "people appear able to create categories on the spot").

4. RICHARD NISBETT \& LEE ROSS, HUMAN INFERENCE: STRATEGIES AND SHORTCOMINGS OF SOCIAL JUDGMENT 33, 167-92 (1980) (discussing theory maintenance and change and how categories are maintained despite data that ought to undermine their deployment).

5. Thomas L. Spalding \& Gregory L. Murphy, What Is Learned in Knowledge-Related Categories? Evidence from Typicality and Feature Frequency Judgments, 27 MEMORY \& COGNITION 856, 856 (1999). 
federalism brings those insights into legal discourse by providing better descriptions of contemporary practices and more desirable goals for federations functioning within a wealth of transnational and local activities. The image of a faceted rock, which results in varied observationsdepending on the cut taken, the angle of the view, and the placement of the source of light--underscores law's choices and the layers through which a single event can be seen.

Multi-faceted federalism refuses to ascribe a single mark of identity to a specific law. Laws may be about both family and equality, about both economic capacity and violence. Multi-faceted federalism presumes that governance cannot accurately be described as residing at a single site. State, federal, and transnational laws are all likely to be relevant. And multifaceted federalism remembers that any assignment of dominion can be transitory. One level of government may preside over a given set of problems for a given period rather than forever. Were one to use this lens, the assignment of regulatory authority would become a self-conscious act of power, exercised with an awareness that a sequence of interpretive judgments, made in real time and revisable in the future, undergirds any current designation of where power to regulate what activities rests. Forms of analysis common in what is called the law of preemption in the United States $^{6}$ would become more frequent. That body of law focuses on the question of whether both state and federal laws can regulate a particular event. In theory, preemption analysis is anchored in deference to congressional choices and proceeds from the assumption that Congress did not intend to dislodge state laws absent express direction or specific conflicts. ${ }^{7}$ In lieu of the abstract exegesis about the Framers' purposes now routine in judicial decisions creating categorical federalism, the judicial

6. Other federations sometimes speak of the problem of parallel and shared "competence." For discussions of current European responses, see generally THE GENERAL LAW OF E.C. EXTERNAL RELATIONS (Alan Dashwood \& Christophe Hillion eds., 2000); and GRÁINNE DE BúRCA, SETTING CONSTitutional LiMITS To EU COMPETENCE? (European Univ. Inst., Robert Schuman Centre Forum Paper, 2001).

7. As currently practiced, in contrast, preemption rulings have sometimes prompted divisions along familiar lines about whether state laws have been displaced by congressional statutes. See, e.g., Lorillard Tobacco Co. v. Reilly, 121 S. Ct. 2404, 2419 (2001) (holding that Congress had, through the Federal Cigarette Labeling and Advertising Act, preempted Massachusetts's regulations relating to outdoor and point-of-sale cigarette advertising). Four dissenters "strongly disagreed." Id. at 2440 (Stevens, J., dissenting, joined by Ginsburg, Breyer, and Souter, JJ.); see also Geier v. Am. Honda Motor Co., 529 U.S. 861 (2000) (holding that the Federal Motor Vehicle Safety Standard, promulgated under the National Traffic and Motor Vehicle Safety Act, preempts a state common-law tort action about when the obligation to provide air bags in cars arose). Justice Breyer issued the Court's decision. Id. at 861-86. The four dissenters, joining an opinion by Justice Stevens, included Justices Souter, Thomas, and Ginsburg. $I d$. at 886 (Stevens, J., dissenting). In contrast, as discussed infra text accompanying notes 229-239, all nine Justices agreed that a provision of Massachusetts law barring state entities from purchasing goods or services doing business with Burma was preempted by federal law. Crosby v. Nat'l Foreign Trade Council, 530 U.S. 363 (2000). 
work would be more narrowly focused on concrete explorations of statutory provisions as applied to specific events. Demanding factful, rather than "factless," discussions could help tether judges to records and statutes, thereby cabining the reach of their decisions.

Multi-faceted federalism not only functions as a means of critique but also invites exploration of the rich veins of federalism beyond the boundaries of contemporary legal discourse, fixated on a bipolar vision of states acting singularly and of a predatory federal govemment. ${ }^{8}$ The contemporary debate about whether to prefer, a priori, the states or the federal government for certain forms of lawmaking misses dynamic interaction across levels of governance. In practice, federalism is a web of connections formed by transborder responses (such as interstate agreements and compacts) and through shared efforts by national organizations of state officials, localities, and private interests. Regional agreements among states are commonplace; coordinated judicial proceedings across state lines are increasing, and many state laws are made uniform through joint efforts. Moreover, localities routinely reach beyond the United States through, for example, resolutions about human rights and "sister cities" programs promoting trade. Categorical federalism ignores such endeavors, but multifaceted federalism calls attention to them to engender analysis of their legal and political legitimacy.

Multi-faceted federalism brings opportunities, but I do not ignore the risk of its admittedly open-ended approach, potentially endangering whatever safe harbors the claimed categorical boundaries provide. Were one to believe either that the constitutional text specifies categorical boundaries with a clarity sufficient to withstand manipulation or that claiming such assignments creates more common good (however defined) than would their alteration, multi-faceted federalism opens up discussions that some want foreclosed. For example, if one assumes a national commitment to "civil rights" and hostility from states, decoupling civil rights from "the national" would jeopardize the symbolic capital gained from such an association." But this country's history is replete with

8. Current categorical federalism also has an internal analytic tension. National powers are assumed to be narrowly specified; ignored is the possibility of interaction-for example, that Congress might have extra leeway in regulating interstate commerce on equality grounds. In contrast, states' prerogatives are seen as emanating from several sources, some textual, some structural, some implicit. See Vicki C. Jackson, Holistic Interpretation: Fitzpatrick v. Bitzer and Our Bifurcated Constitution, 53 STAN. L. REV. 1259, 1274-75 (2001) (explaining this disjunctive approach and arguing that congressional powers under the Commerce Clause ought to be read to have been altered, as the Eleventh Amendment has been, by the enactment of the Fourteenth Amendment).

9. Similarly, if one views intemational human rights as securely within national powers, perceives the federal government as receptive to and able to incorporate positive international norms, and fears that sharing such powers with states would limit or erode such norms, multifaceted federalism has little appeal. E.g., Harold Hongju Koh, Bringing International Law Home, 35 Hous. L. REV. 623, 625-26 (1998) [hereinafter Koh, Bringing International Law Home] 
competing strands of antiliberal as well as liberal lawmaking at the national level. ${ }^{10}$ The collapse of both the first and the second Reconstructions illustrates that, without popular support at all levels, moments of national affiliation to widening norms of equality are fleeting.

My willingness to stray from categorical federalism rests on the premises that it is inaccurate as a description of current practices, that it undermines the ability to hold actors politically accountable, and that it disserves federations to assume that any single level of government is a consistent source of certain sorts of social change. Further, categorical federalism does special harm to those seeking to alter gender relations. Categorical federalism represents a commitment to the coherence of unitary categories; feminism poses a fundamental challenge to a host of categorical claims about the meaning of female and male.

Categories of jurisdiction have particular saliency to women because the legal concept of jurisdiction has served as a vehicle by which to preserve male control, first by a claim that the family was itself a jurisdiction free from state superintendence and then by arguing that the family was a specially situated arena sheltered from government intrusion. ${ }^{11}$ But jurisdiction can also be a means of protest against subordination; alternative governing authorities offer the possibility of changing rules. The achievement of VAWA was not that "the national" replaced local antiviolence work but that it was derived from and supplemented such work, mostly through substantial funding of local programs and symbolically through announcing national rights of personal security for women. The rebuff-that violence against women is beyond Congress's reach because it is "truly local"-reiterates a painful history of using jurisdiction as a justification for patriarchal control.

Part II grounds the analysis of federalism and gender by offering a close examination of efforts to enhance women's equality and economic agency by redressing violence against women. By demonstrating that household work is constitutive of marketplace capacities and that federal law joins state law in regulating the obligations of family members, Part III

(providing a theory of the importation of international law through "interaction, interpretation, and internalization" by means of "vertical domestication" through federal law); Harold Hongju Koh, Why Do Nations Obey International Law?, 106 YALE L.J. 2599 (1997) (focusing on national participation in transnational processes).

10. See, e.g., Rogers M. SMITH, CiviC IdEAls: CONFLICTING VISIONS OF CITIZENSHIP IN U.S. HISTORY (1997).

11. See Linda K. Kerber, No Constitutional Right To Be Ladies: Women and the OBligations OF CITIZENSHIP (1998); Catharine A. MacKinnon, Disputing Male Sovereignty: On United States v. Morrison, 114 HARV. L. REV. 135 (2000); Judith Resnik, "Naturally" Without Gender: Women, Jurisdiction, and the Federal Courts, 66 N.Y.U. L. REv. 1682 (1991); Reva B. Siegel, She, the People: The Nineteenth Amendment, Sex Equality, Federalism, and the Family, 115 HARV. L. REV. (forthcoming 2002); Reva B. Siegel, "The Rule of Love": Wife Beating as Prerogative and Privacy, 105 YALE L.J. 2117 (1996). 
rebuts the claim, proffered by categoricalists, that judges can distinguish among activities that are or are not "economic in nature" and that, in turn, such a dividing line separates national from local power. Also provided is a brief history of twentieth-century federal family laws, making plain both the reach of federal lawmaking about family life and the impracticability of walling off "the federal" from "the family." Part IV turns to the laws of other polities, striving to increase women's equality through measures addressing the interdependencies of market and family work. This discussion examines the repeated efforts within the United States to use federalism as a buffer against "foreign" human rights norms. By tracing the interactions among local, national, and global rights movements, I demonstrate that, because "the foreign" is deeply entrenched within the United States, the proposed boundaries of the nation and the state cannot ward off such "intrusions." Part V acknowledges the anxiety flowing from the inevitable ambiguity of living with multiple legal regimes and sketches what multi-faceted federalism offers for lawmaking in this federated society.

\section{CATEgoRIZING THE COMPLEX: VIOLENCE AgAinst WOMEN}

The Supreme Court ruling in United States v. Morrison provides a vivid instance of and insistence upon a categorical conception of federalism. Passed in 1994, VAWA authorized millions of dollars for programs to train police and to provide shelters. VAWA also created new civil and criminal provisions to ease interstate enforcement of protection orders. ${ }^{12}$ At issue in and held unconstitutional by Morrison was only one provision, termed by Congress a "civil rights remedy," 13 permitting victims of "gendermotivated violence" to bring actions for damages in federal courts.

Congress had held four sets of hearings on VAWA between 1991 and 1994, during which a thick record developed about the role of violence in women's lives. Given that congressional authority was then seen as ample, the issue of federal power to legislate did not claim center stage. Proponents did explain that the Commerce and Equal Protection Clauses provided the constitutional premises for nationwide action. ${ }^{14}$ Factual bases came from witnesses testifying that violence organized women's working lives by placing certain jobs (for example, those requiring dangerous nighttime

12. See 18 U.S.C. $\S \S 2262,2265$ (1994); 42 U.S.C. $\$ \S 3796 \mathrm{gg}, 10416$ (1994).

13. 42 U.S.C. $\$ 13981$ (" $[\mathrm{I}] \mathrm{t}$ is the purpose of this part to protect the civil rights of victims of gender motivated violence....").

14. See, e.g., Violence Against Women: Victims of the System: Hearing on S. 15 Before the S. Comm. on the Judiciary, 102d Cong. 103 (1991) (statement of Prof. Cass R. Sunstein) (discussing Commerce Clause powers); id. at 87-88 (statement of Prof. Burt Neuborne) (addressing Equal Protection Clause powers). 
travel) out of reach. ${ }^{15}$ Data produced by some twenty states' judiciaries documented widespread discriminatory practices against female victims of violence by police, prosecutors, judges, and jurors. ${ }^{16}$

In 1995, a year after VAWA passed, the Supreme Court imposed new standards on congressional exercise of its powers. In United States $v$. Lopez ${ }^{17}$ a five-person majority held unconstitutional a federal criminal statute permitting prosecution of individuals alleged to possess guns within 1000 feet of a schoolyard. The Lopez Court blamed the congressional record for failing to identify the relationship between guns near schoolyards and interstate commerce; lacking was a showing that the regulated activity had a "substantial effect" on interstate commerce. ${ }^{18}$ For some, the lesson of Lopez was that Congress could not name something "commerce" without offering sufficient bases for its action, but that Lopez only required a coordinate branch to engage in more factfinding. ${ }^{19}$

When the legality of the congressional action was subsequently before the Supreme Court, its proponents therefore distinguished the bare record in Lopez from the fact-filled record in VAWA. Rather than relying only on a generic, aggregate-effects-on-the-economy claim akin to that rejected in Lopez, ${ }^{20}$ VAWA's advocates also pointed to record evidence that violence targeted against women qua women limited their economic options. ${ }^{21}$ Proponents argued that, just as the Court had accepted the Commerce Clause as a proper predicate for civil rights legislation aimed at reducing barriers to commerce for African Americans in the $1960 \mathrm{~s},{ }^{22}$ it should do the same for gender in the 1990s. Further, to rebut the claim of national intrusion on state prerogatives, proponents focused on the limited and supplemental nature of the federal remedy, supported by thirty-nine state

15. See, e.g., Violence Against Women: Fighting the Fear, Examining the Rise of Violence Against Women in the State of Maine and in Other Rural Areas: Hearing Before the S. Comm. on the Judiciary, 103d Cong. 13-17 (1993) (statement of Lisa (full name not provided)); Violence Against Women: Victims of the System: Hearing on S. 15 Before the S. Comm. on the Judiciary, 102d Cong. 239-41 (1991) (statement of Elizabeth Athanasakos, National President, National Federation of Business and Professional Women, Inc.); S. REP. No. 103-138, at $54 \mathrm{n} .70$ (1993).

16. See, e.g., H.R. CONF. REP. No. 103-711, at 385-86 (1994); S. REP. No. 103-138, at 41-55 (1993); S. REP. No. 102-197, at 33-35, 41, 43-47 (1991); see also United States v. Morrison, 529 U.S. 598, 631 n.7 (2000) (Souter, J., dissenting) (listing the reports).

17. 514 U.S. 549 (1995).

18. Id. at 561-63.

19. See, e.g., Charles Fried, The Supreme Court, 1994 Term-Foreword: Revolutions?, 109 HARV. L. REV. 13, 37-42 (1995) (describing "the modesty of the Court's work" in Lopez).

20. 514 U.S. at 564 .

21. See Brief for the United States at 5-8, 23-27, Morrison (Nos. 99-5, 99-29), 1999 WL 1037259; Brief of Law Professors as Amici Curiae in Support of Petitioners at 5-12, Morrison (Nos. 99-5, 99-29), 1999 WL 1032805 [hereinafter Law Professors' Amici Brief]. I was one of several who wrote the latter brief, filed on behalf of some one hundred law professors.

22. See Katzenbach v. McClung, 379 U.S. 294, 302-03 (1964); Heart of Atlanta Motel v. United States, 379 U.S. 241, 252-62 (1964). 
attorneys general before it was enacted ${ }^{23}$ and by thirty-six when its constitutionality was before the Supreme Court. ${ }^{24}$

The majority opinion in Morrison is, in contrast, notably "factless," by which I mean that it refused to engage with the record before it. The majority did not delve into the claimed relationship between market participation and gender-targeted violence, nor did it interrogate whether and in what fashion states were harmed by the provision of a supplemental civil cause of action in federal court. Rather, the majority stipulated that aggression against women was "non-economic, criminal violent conduct." 25 The majority then argued that, if Congress could regulate such criminal activity, it could "equally as well" regulate "family law and other areas of traditional state regulation since the aggregate effect of marriage, divorce, and childbearing on the national economy is undoubtedly significant." 26

Why did the Morrison majority-and even more so, the en banc Fourth Circuit decision below ${ }^{27}$ - view VAWA as a federal assault on state governance of the family? Morrison itself did not involve family members. A young woman university student, alleging that two male co-students had raped her, filed the VAWA complaint, ${ }^{28}$ assumed by the lower courts sufficient to show animus based on gender. ${ }^{29}$ Similarly, almost half of the fifty reported decisions on VAWA's civil rights remedy had likewise

23. See Letter from Robert Abrams, Attorney General of New York on Behalf of His Colleagues to Congressman Jack Brooks, Chair of the House Judiciary Committee (July 22, 1993), in Crimes of Violence Motivated by Gender: Hearing Before the Subcomm. on Civil and Constitutional Rights of the House Comm. on the Judiciary, 103d Cong. 34 (1993). The thirtynine state attorneys general were joined by the attomeys general of the District of Columbia and Guam. Id.

24. See Brief of the States of Arizona et al. in Support of Petitioners, Brief on the Merits, Morrison (Nos. 99-5, 99-29), 1999 WL 1032809 (arguing VAWA's constitutionality on Commerce Clause grounds). Only one state-Alabama-filed in support of its invalidation. See Brief for the State of Alabama as Amicus Curiae in Support of Respondents, Morrison (Nos. 99-5, 99-29), 1999 WL 1191432.

25. Morrison, 529 U.S. at 617 ; see also id. at 613 ("Gender-motivated crimes of violence are not, in any sense of the phrase, economic activity."). A second ground for decision was that, because the statute authorized damage actions against nonstate defendants, Congress could not rely on its Fourteenth Amendment powers. Id. at 619-27. See Robert C. Post \& Reva B. Siegel, Equal Protection by Law: Federal Antidiscrimination Legislation After Morrison and Kime], 110 YALE L.J. 441, 473-509 (2000) (criticizing this aspect of the opinion).

26. Morrison, 529 U.S. at 615-16. banc).

27. See Brzonkala v. Va. Polytechnic Inst., 169 F.3d 820, 842-43, 896 (4th Cir. 1999) (en

28. Christy Brzonkala, a student at Virginia Polytechnic Institute, alleged that she had been raped by two athletes, one of whom later claimed, "I like to get girls drunk and fuck the shit out of them." See Brzonkala v. Va. Polytechnic Inst., 935 F. Supp. 779, 784 (W.D. Va. 1996). The university initially imposed a sanction of an immediate two-semester suspension on one of the assailants but later reduced it to a deferred suspension (after graduation) and a required one-hour educational program. Brzonkala v. Va. Polytechnic Inst., 132 F.3d 949, 955 (1996) (Motz, J., dissenting).

29. Id. at $785 ;$ Brzonkala, 169 F.3d at 830 . 
involved work or educational settings, not interactions within families. ${ }^{30}$ Moreover, Congress had precluded federal courts from exercising their ordinarily available powers of supplemental jurisdiction over claims raised between VAWA plaintiffs and defendants if related to divorce, alimony, or child custody, ${ }^{31}$ thereby creating a statutory barrier to any "family" issues attempting to ride the coattails of a VAWA lawsuit. Yet the Morrison majority equated a complex set of legal regulations with the categories of family and crime, located those categories as subject to state governance, insisted on the naturalness of the division, and assumed the federal/state options to be bipolar and exclusive. Through categorical federalism, Morrison established the Court's role as superintendent over Congress's exercise of its Commerce Clause powers, just as the Court (or more accurately, its now famous five-person majority) has claimed its authority over congressional implementation of the Fourteenth Amendment. ${ }^{32}$

\section{The FAILINGS OF CATEgorical FEDERALiSM: PICKING AND CONSTRUCTING BOXES}

Two kinds of defects undermine the claimed coherence of categorical federalism: Category mistakes are common, and permanent categorization is itself a mistake. The first objection, about category errors, offers a critique from within the normative framework of categorical federalism, while the second objects to the framework itself. This Part makes both arguments by excavating the stipulated truths (that violence against women is not "economic in nature," that the Constitution requires a distinction between "the truly national" and the "truly local," and that family law is the domain of states) proffered by the Morrison majority to obscure its own role in making the meaning of commerce, of women's roles and the import of violence, and of the relationships among state law, federal law, and family life.

I begin by probing the idea of something being "economic in nature" and, after detailing the relationships between gender, householding, and wage work, question why federal laws aimed at protecting women failed this test. I also demonstrate the malleability of the naturally economic by looking at post-Morrison decisions finding debts to pay child support not "economic in nature" but laws prohibiting possession of child pornography and protecting wolves in the wild sufficiently "commercial in character" to

30. See Law Professors' Amici Brief, supra note 21, at 3-15.

31. 42 U.S.C. $\$ 13981$ (e)(4) (1994) (altering the effects of 28 U.S.C. $\$ 1367$ ).

32. See Fla. Prepaid Postsecondary Educ. Expense Bd. v. Coll. Sav. Bank, 527 U.S. 627 (1999); City of Boerne v. Flores, 521 U.S. 507, 519-20 (1997). For critical analyses of the Court's approach, see generally Evan H. Caminker, "Appropriate" Means-Ends Constraints on Section 5 Powers, 53 STAN. L. REV. 1127 (2001); and Post \& Siegel, supra note 25. 
permit federal lawmaking. Brought to the fore is the role played by morality; certain forms of federal morals legislation pass even contemporary Commerce Clause tests. Thereafter, I turn to the relationship between federal law and families. Assuming for that discussion the propriety of the Morrison majority classification of VAWA as about family and criminal law, I disagree with its proposition that the "federal" has no role to play. Rather, the extant legal patterns are best described as multifaceted federalism in which state and federal laws cohabit.

\section{A. "Economic in Nature"}

\section{Gender and Economic Agency}

The Morrison majority claimed that violence against women was not "economic in nature." ${ }^{33}$ Even as it constructed this category, the majority denied its own role in making it:

While we need not adopt a categorical rule against aggregating the effects of any noneconomic activity in order to decide these [commerce] cases, thus far in our Nation's history our cases have upheld Commerce Clause regulation of intrastate activity only where that activity is economic in nature. ${ }^{34}$

What could "economic in nature" mean? The phrase is one coined relatively recently by judges ${ }^{35}$ rather than found in the literature of economics, which does not evidence much of a sense that it has "natural" boundaries ${ }^{36}$ Economists proffer analyses for an array of human activity, including family life. ${ }^{37}$ Consider also the boundary-bending term "home economics," coined a century ago to make plain that tasks once thought

33. United States v. Morrison, 529 U.S. 598, 613 (2000).

34. Id.

35. The phrase appeared in a few Supreme Court decisions before Morrison. See, e.g., BMW of N. Am., Inc. v. Gore, 517 U.S. 559, 576 (1996) (equating "economic in nature" with the dollar value of damage to a car); Fullilove v. Klutznick, 448 U.S. 448, $511-12$ n.11 (1980) (Powell, J., concurring) (quoting congressional reports describing the problems faced by minority businesses as "economic in nature"). In one deployment, Justice Brennan described economic injury as a facet of the burdens flowing from discrimination. United States v. Kozminski, 487 U.S. 931, 958 n.5 (1988) (Brennan, J., joined by Marshall, J., concurring) (arguing that criminal statutes enacted to enforce the Thirteenth Amendment ought to protect against injuries from involuntary servitude that are "psychological, social, and economic in nature" and disagreeing with the majority requirement of a showing of "physical or legal coercion").

36. See Tanina Rostain, Educating Homo Economicus: Cautionary Notes on the New Behavioral Law and Economics Movement, 34 LAW \& SOC'Y REV. 973 (2000) (criticizing the broad ambitions and the narrow lens of behavioral economics).

37. See, e.g., GaRY S. BeCKER, A TREATISE ON THE FAMILY (2d ed. 1991). 
definitional of household labor-laundry, baking, and making clotheshad, by the early 1900 s, become associated with the market. ${ }^{38}$

The interplay between markets and homes was and is thick. ${ }^{39}$ Federal funds supported education in home economics as a part of vocational training; $;^{40}$ efforts at "municipal housekeeping" aimed to improve localities; ${ }^{41}$ and businesses relied on home economists to market products to consumers. ${ }^{42}$ Contemporary feminist arguments address the lack of market value accorded to work within households ${ }^{43}$ Some seek to have that work commodified as a means of underscoring that, in two-adult households, women's work inside the household subsidizes and enables wage-earning outside the household. Once women are understood as economic agents when at home as well as when at wage workplaces, laws prohibiting attacks on women in or outside their homes can similarly be understood as protecting and enabling economic capabilities.

That violence against women, in particular, should not be included within activities that are "economic in nature" is painfully ironic. Women were once understood as all too "economic in nature," as a species of property, a bundle of goods and services. ${ }^{44}$ The Supreme Court has many

38. See Sarah Stage, Home Economics: What's in a Name?, in RETHINKING HOME ECONOMICS: WOMEN AND THE HISTORY OF A PROFESSION 1, 5-6 (Sarah Stage \& Virginia B. Vincenti eds., 1997) [hereinafter RETHINKING HOME ECONOMICS] (discussing the consideration of other terms-"household arts," "domestic economy," and "domestic science"-at conferences that resulted in the creation of the American Home Economic Association in 1909). Federal grant programs for agricultural studies also linked the words home and economic. See, e.g., First Morrill Act of 1862, 7 U.S.C. $\S \S 301-308$ (1994) (funding the teaching of mechanical and agricultural arts); Smith-Lever Act of 1914, 7 U.S.C. \$\$ 341-342 (promoting "the development of practical applications of research knowledge ... in agriculture, home economics, and rural energy").

39. See Frances E. Olsen, The Family and the Market: A Study of Ideology and Legal Reform, 96 HARV. L. REV. 1497 (1983).

40. Projects were promoted through the Department of Agriculture, which in 1923 established the Bureau of Home Economics. That Bureau detailed its activities yearly. The Reports of the Chief of the Bureau of Home Economics were published annually from 1924 to 1942 in the Annual Reports of the Department of Agriculture.

41. See MARY RITTER BEARD, WOMAN's WORK IN MUNICIPALITIES (1915) (invoking the home both as a template for the municipality and as a haven from it); NANCY TOMES, THE GOSPEL OF GERMS: MEN, WOMEN AND THE MiCROBE IN AMERICAN LIFE 183-233 (1998) (detailing the link between the home economics movement and the public health movement).

42. See, e.g., Ronald R. Kline, Agents of Modernity: Home Economists and Rural Electrification, 1925-1950, in RETHINKING HOME ECONOMICS, supra note 38, at 237, 239 (discussing the "large number of home economists who worked in a vast network of manufacturers, utility companies, state colleges, government agencies, and farm cooperatives to electrify rural America").

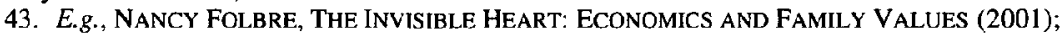
JOAN WILLIAMS, UNBENDING GENDER: WHY FAMILY AND WORK CONFLICT AND WHAT TO DO ABOUT IT (2000); Reva B. Siegel, Home as Work: The First Woman's Rights Claims Concerning Wives' Household Labor, 1850-1880, 103 Y ALE L.J. 1073 (1994).

44. See KeRBER, supra note 11, at 11-29 (discussing the American incorporation of English laws of the family, including the practice of coverture, in which women, upon marriage, lost control over their property and had no civic identity); Gayle Rubin, The Traffic in Women: Notes on the "Political Economy" of Sex, in TOWARD AN ANTHROPOLOGY OF WOMEN 157 (Rayna R. 
times acknowledged that women can be treated as commodities. For example, in the early part of the twentieth century, the Court upheld the Mann Act (named after its sponsor) making illegal the transportation of women for "immoral purposes" across state lines. ${ }^{45}$ Despite the defendant's argument that no money had been exchanged for sex, ${ }^{46}$ the Court approved the statute by analogizing the movement of women to that of articles of merchandise. ${ }^{47}$ This law remains in use. ${ }^{48}$ More recent legislation also addresses the treatment of women as property by penalizing "trafficking," 49 which is on the rise as an artifact of current forms of globalization. ${ }^{50}$ Yet, when women seek to be holders and producers of property, to be players in the market, thinking about women in economic terms is claimed to be a category error.

Even some commentators who seek to engender more national rightsmaking would rather avoid the language of commerce-arguing that it dilutes commitments to freedom and status transformation. ${ }^{51}$ The strategic reason why VAWA relied on commerce powers is understood. In the

Reiter ed., 1975) (relying on anthropological data to demonstrate the "gifts" of women and the ways in which they performed intersocietal commercial and political functions).

45. Caminetti v. United States, 242 U.S. 470 (1917).

46. Petition for a Writ of Certiorari at 8, Caminetti (No. 139) (arguing that while the statute could lawfully be applied to commercialized sex, it should not be applied to conduct "objectionable only for its immorality").

47. Caminetti, 242 U.S. at 491-93. Further, the Court recognized that Congress had intended to regulate interstate transportation of women not only for economic gain but also if incidental to an "immoral purpose," construed to include inducing a woman to become a prostitute or "a concubine or mistress." Id. at 485-89.

48. In 1986, the Mann Act was amended to make its terms gender neutral and to limit its application to interstate transportation for prostitution or "any sexual activity for which any person can be charged with a criminal offense," thereby linking its provisions to state laws governing sexual behavior. See Child Sexual Abuse and Pornography Act of 1986, Pub. L. No. 99-628, 100 Stat. 3511-12 (codified at 18 U.S.C. $\$ \S 2421-2423$ (1994)) (addressing coercion and minors); H.R. REP. No. 99-910 (1986).

49. See Victims of Trafficking and Violence Protection Act of 2000, Pub. L. No. 106-386, 114 Stat. 1464 (codified at 22 U.S.C.A. $\$ \S 7101-7110$ (West Supp. 2000)); Ratna Kapur, The Tragedy of Victimisation Rhetoric: Resurrecting the "Native" Subject in International/PostColonial Feminist Legal Politics (2001) (unpublished manuscript, on file with author) (arguing that interest in regulation of sexuality and a focus on violence against women reinforce the image of women as victims and may inhibit their emancipation).

50. See Saskia Sassen, Women's Burden: Counter-Geographies of Globalization: The Feminization of Survival, 53 J. INT'L AFF. 503 (2000) (discussing how the migration of money and people reflects the relationships among debt levels, tourist trades, and transactions in humans); see also Marjan Wijers, European Union Policies on Trafficking in Women, in GENDER POLICIES IN THE EUROPEAN UNION 209 (Mariagrazia Rossilli ed., 2000) (providing an overview of differing approaches member states take with regard to sex workers and whether such workers should have the option of that form of work, in part to enable migration).

51. See, e.g., James Gray Pope, The Thirteenth Amendment Versus the Commerce Clause: Labor and the Shaping of the Post-New Deal Constitutional Order, 1921-1957, 102 COLUM. L. REV. (forthcoming Jan. 2002) (arguing that, had New Deal labor legislation been supported through elaboration of the Thirteenth Amendment rather than based on Congress's power over commerce, a broader understanding would have developed, forestalling the contemporary retrenchment). 
1960s, the Supreme Court had avoided questions about congressional power to reach "private" actors under the Fourteenth Amendment by relying on the Commerce Clause to uphold civil rights legislation. Yet, say such objectors, congressional power to deal with violence against women ought to be understood as related to equality, not commerce. ${ }^{52}$

But framing the problem of violence against women as embedded in commerce provides descriptive accuracy and normative instruction about the degree to which the current economy is formed by gendered allocations of work that subordinate women. Obtaining equality for women depends upon their gaining recognition as commercial actors. Virginia Woolf explained it well in 1928 when she compared the value of the right to vote (then recently won) with the receipt of a regular income (specifically her new "legacy" of "five hundred pounds a year"): "The money, I own, seemed infinitely the more important." ${ }^{53}$ Her book's title-A Room of One's Own-reflects the power to control one's physical space. "[T]hat five hundred a year stands for the power to contemplate, ... a lock on a door means the power to think for oneself." 54

A locked room denotes a safe space, a home. Yet many women do not have that safety, as home-based aggression blocks their access to participation in the national economy. Once out the door, the fear of walking down deserted streets, of using public transportation at night, and of entering empty corridors disproportionately affects women, who regularly report surveying their surroundings as a protective measure. ${ }^{55}$ Moreover, once at work, physical threats remain for women. The law of sexual harassment now marks the idea that women are harmed at work because they are women. But the term "sexual harassment" may mask (for some) that not only are women confronted with threats of sex, they are also sometimes physically assaulted. ${ }^{56}$ The argument is not that every act of

52. See, e.g., Akhil Reed Amar, The Supreme Court, 1999 Term-Foreword: The Document and the Dactrine, 114 HARV. L. REV. 26, 103 ("Candid supporters of VAWA can concede that the issue of violence against women is not mainly an economic one, or chiefly an interstate one.").

53. VIRGINIA WOOLF, A ROOM OF ONE'S OWN 37 (Harcourt, Brace \& World, Inc. 1957) (1929). She gained that income at about the same time, 1919, that women gained the right to vote in England. Id. at 37, 116.

54. Id. at 110 .

55. See Margaret T. Gordon \& Stephanie Riger, The Female Fear (1989); Cynthia Grant Bowman, Street Harassment and the Informal Ghettoization of Women, 106 HARV. L. REV. 517 (1993). Aggregate data from 1994 indicate that women are more likely to be victimized in private homes by people known to them, while men are more likely to be victimized in public places by strangers. See Diane CRAVEN, SEX DifFERENCES IN VIOLENT VICTIMIZATION, 1994, at 1, 4, 6 (Bureau of Justice Statistics, Special Report NCJ-164508, 1997), http://www.ojp.gov/bjs/ $\mathrm{pub} / \mathrm{pdf} / \mathrm{sdvv}$.pdf. Women's fear of public spaces may be exaggerated or their fear of private places may be too low. Alternatively, women's fear of public spaces may prompt them to be careful, thereby lowering their rate of injury.

56. See Rosa Ehrenreich, Dignity and Discrimination: Toward a Pluralist Understanding of Workplace Harassment, 88 GEO. L.J. 1 (1999); Vicki Schultz, Reconceptualizing Sexual 
violence directed at women is aimed at undermining economic capacity but that, cumulatively, the volume of violence directed against women limits women's roles as commercial actors and as wage-workers. Decades ago, Commerce Clause jurisprudence shifted to acknowledge the interrelationship between production and sales and to take into account that enterprises like insurance and agriculture, once thought to be "local," are too much a part of the national economy to be exempt from federal regulation. ${ }^{57}$ Commerce Clause jurisprudence could shift again, now to acknowledge that activities such as gender-targeted violence, once conceived as external to the economy, are constitutive of it. ${ }^{58}$ That federal powers are enumerated does not tell us what content they have.

\section{Endangered Children and Wolves}

In Morrison's wake, the category of "the economic" has taken on a vitality that opens up challenges to many federal statutes about topics

Harassment, 107 YALE L.J. 1683 (1998). For a discussion of economic coercion, see BARBARA A. GUTEK, SEX AND THE WORKPLACE (1985).

57. Recall the Court's view in 1895 that "[ $t]$ he fact that an article is manufactured for export to another state does not of itself make it an article of interstate commerce." United States v. E.C. Knight Co., 156 U.S. 1, 9 (1895). That ruling was a part of a series of cases rejecting congressional regulations based on the Commerce Clause over a range of activities, including manufacturing monopolies, E.C. Knight Co., 156 U.S. 1, insurance, N.Y. Life Ins. Co. v. Deer Lodge County, 231 U.S. 495 (1913), and labor relations at mines, Carter v. Carter Coal Co., 298 U.S. 238 (1936). As the E.C. Knight Co. Court explained, to do otherwise would be to permit Congress to regulate "every branch of human industry," resulting in regulation of "interests which in their nature are and must be local in all the details of their successful management." E.C. Knight Co., 156 U.S. at 14-15. Similarly, the Court in New York Life Insurance Co. invoked the image of "contracts purely domestic in their nature." 231 U.S. at 506 (citations omitted).

While subsequent revisions came through holdings that manufacturing, NLRB v. Jones \& Laughlin Steel Corp., 301 U.S. 1 (1937), and agriculture, Wickard v. Filburn, 317 U.S. 111 (1942), were parts of interstate commerce, the predicates for the earlier decisions parallel those invoked today. The majority, then and now, assumes that congressional power must be contained, that the means to do so is to categorize some form of activity as local "in nature," and, as a consequence, that the implausibility of the constitutionality of congressional regulation becomes plain on its face.

58. Others make a different claim, that the ambiguity and breadth of the category of the "commercial" in Morrison permits Congress to reach all crimes "fundamentally financial in nature, such as fraud or theft" as well as certain forms of violence. See Jesse H. Choper \& John C. Yoo, The Scope of the Commerce Clause After Morrison, 25 OKLA. CITY U. L. REV. 843, 866 (2000) (arguing that if "domestic violence" involved a "commercial transaction-such as purchasing a weapon, renting a car or hotel room," it might also be subject to congressional prohibition). In a similar vein, Representative John Conyers introduced a bill creating a civil cause of action for a crime "motivated by gender" if "the defendant or the victim travels in interstate or foreign commerce" or uses "a facility or instrumentality" of interstate or foreign commerce or a weapon that had traveled in interstate or foreign commerce, or if the "offense interferes with commercial or other economic activity in which the victim is engaged at the time of conduct." See Violence Against Women Civil Rights Restoration Act of 2000, H.R. 5021, 106th Cong. (2000) (proposing also that the Attomey General have the discretion to bring actions against states, subdivisions, or their officials for parterns of discrimination "on the basis of gender in the investigation or prosecution of gender-based crimes"). 
ranging from debt repayment to child pornography to endangered species. As the case law grows, we have come to learn that not all kinds of debt are "economic in nature" but that some wild animals are sufficiently a part of the economy as to permit congressional action.

A first example is the Child Support Recovery Act (CSRA), ${ }^{59}$ enacted in 1992 and modified in 1998. The statute makes certain willful failures to pay child support, if noncustodial parents live in another state, a federal offense. ${ }^{60}$ In the years before Morrison, several defendants challenged the CSRA, all unsuccessfully, as circuit after circuit found it constitutional. ${ }^{61}$ As one commentator explained, the reason for unanimity was "simple: The CSRA is within Congress's Commerce Clause power because the statute regulates the payment (or nonpayment) of money across state lines." ${ }^{62}$ Further, federal oversight of interstate obligations is not unique to this context; "jurisdiction jumping" is also a phenomenon in bankruptcy. ${ }^{63}$

Since Morrison, however, a few lower courts have held the CSRA unconstitutional on the ground that, like VAWA, it relates to a sphere of human activity inappropriate for national legislation. While lower court judges disagree, these decisions illuminate the ongoing effort to curb federal power through categorical claims about the economic import of family life. For example, according to one decision, child support debt was not "commercial in nature," described as the "mutual exchange of value motivated by economic self-interest," ${ }^{64}$ because orders to pay child support lack "this essential feature of reciprocity." 65

59. 18 U.S.C. $\S 228$ (1994), amended by Deadbeat Parents Punishment Act of 1998, Pub. L. No. $105-187,112$ Stat. 618.

60. 18 U.S.C. $\$ 228$ (a)(1) (1994 \& Supp. V 1999) (criminalizing the failure of a parent in one state to pay child support for a period of more than a year or of an amount "greater than $\$ 5,000$ " if done so "willfully ... with respect to a child who resides in another State"). Further, any person who "travels in interstate or foreign commerce with the intent to evade a support obligation, if such obligation has remained unpaid for a period longer than 1 year, or is greater than $\$ 5,000 "$ may also be subjected to felony punishments. 18 U.S.C. $\$ 228(a)(2)$. The 1998 amendments increased penalties against those who "attempt to escape state-issued child support orders by fleeing across state lines." See 144 CoNG. REC. H3044 (daily cd. May 12, 1998) (statement of Rep. Steny H. Hoyer).

61. See, e.g., United States v. Black, 125 F.3d 454 (7th Cir. 1997), cert. denied, 523 U.S. 1033 (1998); United States v. Johnson, 114 F.3d 476 (4th Cir. 1997); United States v. Sage, 92 F.3d 101 (2d Cir. 1996).

62. Michacl A. Simons, Prosecutorial Discretion and Prosecution Guidelines: A Case Study in Controlling Federalization, 75 N.Y.U. L. REV. 893, 948 (2000).

63. See G. Marcus Cole, The Federalist Cost of Bankruptcy Exemption Reform, 74 AM. BANKR. L.J. 227, 229 (2000) (discussing "the market for deadbeats" by considering how variations in laws can facilitate exit strategies for certain kinds of debtors).

64. See United States v. Faasse, 227 F.3d 660, 664 (6th Cir. 2000) (holding the 1992 statute unconstitutional because it imposed liability not for "recovery of child support payments avoided by interstate flight ... [but only based on] obligations owed by one family member to another, using diversity of residence as a jurisdictional 'hook'"). That decision was subsequently vacated pending reargument en banc, 234 F.3d 312 (6th Cir. 2000), and then reversed in United States v. Faasse, No. 98-2337, 2001 WL 1058237 (6th Cir. Sept. 14, 2001). Four judges dissented, reiterating the claim of an absence of "reciprocity," id. at *15 (Batchelder, J., dissenting, joined 
The idea of the family as a nonreciprocal entity stems from eras in which male patriarchs had power over both wives and children. Law enforced that regime in many ways. Wives were not legally competent to enter contracts or to bring lawsuits. Federal diversity jurisdiction was itself unavailable because the husband and wife, legally one, could not be citizens of different states. Once laws of coverture were jettisoned, however, such jurisdictional prohibitions and laws of interspousal immunity began to fall. ${ }^{66}$ Adults in household units gained the status of legally interrelated, independent adults, both of whom were required to support their minor children.

Law has done more than abolish prior practices; it has imposed new obligations on family members. For example, custodial parents receiving federally supported benefits must assist in obtaining child support from noncomplying co-parents or risk a loss of benefits. ${ }^{67}$ Federal statutes thus use one parent's economic self-interest to motivate her (or, infrequently, him) to help the government pursue the other. Markets also reinforce the interdependent economic obligations within households; work time spent in providing care to one's own children reduces work time for wage earning. ${ }^{68}$ As a consequence, partners in marriage, ex-partners in divorce, and nevermarried coventurers often rely on "mutual promises and bargains," ${ }^{69}$ as do other contracting parties.

by Boggs, Norris, and Suhreheinrich, JJ.), and protesting the majority decision as licensing "virtually limitless federal police power" in violation of current Supreme Court law, id. at *14.

65. Faasse, 227 F.3d at 670. Faasse also concluded that the CSRA interfered with Michigan's family law policies by criminalizing acts that the state did not, id. at $664-65$, and that Congress had no power to regulate debts "merely because the obligor and obligee reside in different states," id. at 668 .

66. A contemporary doctrine-the "domestic relations exception" to diversity jurisdictionis a legacy of that regime. Although the congressional grant of diversity does not mention such an exclusion, the Supreme Court has construed the diversity statute to require that federal courts decline to adjudicate cases between citizens of different states involving the requisite dollar amount if the litigants dispute issues related to marriage, alimony, divorce, or child custody. In contrast, tort disputes between family or former family members were not held to be outside federal diversity jurisdiction. See Ankenbandt v. Richards, 504 U.S. 689 (1992).

67. 42 U.S.C. $\$ 602$ (a)(26) (1994). The pressures to comply are substantial. See ANNE CASE, I-FEN LIN \& SARA MCLANAHAN, UNDERSTANDING CHILD SUPPORT TRENDS: ECONOMIC, DEMOGRAPHIC, AND POLITICAL CONTRIBUTIONS (Nat'l Bureau of Econ. Research, Working Paper No. 8056, 2000) (discussing the centrality of child support payments as sources of income for single mothers).

68. Christian Dustmann \& Christoph M. Schmidt, The Wage Performance of IMMIGRANT WOMEN: Full-TIME JOBS, PART-TIME JOBS, AND THE ROLE OF SELECTION (Ctr. for Econ. Policy Research, Discussion Paper Series No. 2702, 2001) (providing a case study detailing how husbands and children affect women's participation in wage-work).

69. This language comes from a decision upholding the Freedom of Access to Clinic Entrances Act (FACE), which distinguished the CSRA decisions on the ground that, unlike stateimposed child support orders, clinics rely on "mutual promises and bargains by suppliers, doctors, patients, and other employees." Norton v. Reno, No. 4:00-CV-141, 2000 WL 1769580, at *6 (W.D. Mich. Nov. 24, 2000). 
Yet some federal judges, attempting to shift the focus from the custodial parent to the child as creditor, ${ }^{70}$ reject the concept that debts arising from parenthood reflect reciprocal agreements on the allocation of work between parents. Further, national laws are claimed to interfere impermissibly with state prerogatives. ${ }^{71}$ As another federal judge explained:

The Supreme Court's current federalism jurisprudence teaches that the CSRA, by making it a federal crime to fail to make child support payments-a matter of family law-based merely on the fact that the parent and child reside in different states, upsets the delicate balance "between what is truly national and what is truly local." 72

In contrast, statutes prohibiting conduct less readily commodifiable have survived Morrison challenges, as the term "economic in nature" is supplemented with the concept that something can be "commercial in character." 73 One example comes from constitutional objections lodged by criminal defendants charged with possession of sexually explicit depictions of minors if those depictions or the materials used to produce them were shipped in interstate commerce. ${ }^{74}$ Courts have concluded that possession of such photographs, even when self-generated and not intended for commercial use, is enough like the production of local wheat in Wickard v. Filburn $^{75}$ to qualify as economic activity. Why? Because local possession of photos "interacts with a national market on both the supply and demand side," thereby justifying a congressional conclusion that it had power to reach the activity. ${ }^{76}$ Unlike the majority in Morrison, reluctant to accede to

70. See Faasse, 2001 WL 1058237 , at $* 24$ n. 1 (Batchelder, J., dissenting).

71. Id. at *23 (stating that the "Act emasculates the states' ability to assign social and other costs to the disobedience of child support orders").

72. United States v. King, No. 5300 Cr. 653, 2001 WL 111278, at *6 (S.D.N.Y. Feb. 8, 2001); see also United States v. Benton, No. 00-4864, 2001 WL 876901 (4th Cir. Aug. 3, 2001) (concluding, in an unpublished disposition, that the Fourth Circuit's prior view of the constitutionality of the CSRA was unaltered by Morrison). But see United States v. MacWeeney, No. 00 Cr. 0223, 2000 WL 1634400 (S.D.N.Y. Oct. 31, 2000) (distinguishing Morrison in a decision holding constitutional the 1998 version of the CSRA, discussed supra note 59).

73. See, e.g., United States v. Kallestad, 236 F.3d 225, 228 (5th Cir. 2000).

74. 18 U.S.C. \& 2252(a)(4)(B) (1994 \& Supp. V 1999). This provision was amended in 1998 to make the possession of one or more (as contrasted with three or more) sexually explicit depictions of a minor an offense. See Protection of Children from Sexual Predators Act of 1998, Pub. L. No. 105-314, § 203(a)(1), 112 Stat. 2977, 2978 (codified at 18 U.S.C. $\$ 2252(a)(4)(B)$ ).

75. 317 U.S. 111 (1942).

76. Kallestad, 236 F.3d at 230 (distinguishing the "rape at issue in Morrison"). A dissenter protested that:

[T] his simple local possession of self-generated pornographic material, where no commercial activity was involved, no interstate transportation took place, and no congressional findings support the necessity of such regulation in the framework of a broader regulatory scheme, is beyond the reach of any reasonable interpretation of Congress' Commerce Clause power. 
congressional assessments about women and violence, these judges readily relied on congressional views of the need for national protection against possession of child pornography. ${ }^{77}$

"Judicial deference to the judgment of the democratic branches" 78 was also in evidence in a Fourth Circuit decision, Gibbs v. Babbitt, which provides further insight into the plasticity of the new commerce jurisprudence. A man shot a wolf who had strayed onto private lands; he was charged under federal laws making it illegal to "harass, harm, pursue, hunt, shoot, wound, kill, trap, capture, or collect" any threatened or endangered species. ${ }^{79} \mathrm{His}$ challenge raised the question of congressional power to protect endangered species on private property. Recall that judges within the Fourth Circuit were the first to hold that violence against women was not related to commerce. ${ }^{80}$ In contrast, in Gibbs v. Babbitt, the circuit concluded that "economic activity must be understood in broad terms... not ... limited to its '18th-century' forms." ${ }^{81}$ Because the motivation to harm wolves came from farmers and ranchers worried about commercially valuable livestock, because wolves had been and might again be hunted for their pelts, because wolves were part of a "national wildlife-related recreational industry that involves tourism and interstate travel," 82 and because the regulation of red wolf takings was "also closely connected to a second interstate market-scientific research"- which generated jobs ${ }^{83}$ and might also lead to "other potential economic activities," ${ }^{84}$ it was up to

Id. at 233 (Jolly, J., dissenting); see also United States v. Buculei, 262 F.3d 322 (4th Cir. 2001) (distinguishing Morrison and Lopez); United States v. Rodia, 194 F.3d 465 (3d Cir. 1999), cert. denied, 529 U.S. 1131 (2000) (relying also on a market stimulation theory, as well as an analogy to addiction); United States v. Angle, 234 F.3d 326 (7th Cir. 2000) (agreeing with the Third Circuit). For other courts, the interstate nexus (photographs taken with film or by a camera made in a state other than that of the defendant) suffices. See United States v. Robinson, 137 F.3d 652 (1st Cir. 1998); United States v. Bausch, 140 F.3d 739 (8th Cir. 1998), cert. denied, 525 U.S. 1072 (1999).

77. Kallestad, 236 F.3d at 229. That court relied on the commercial nature of the activity because, in its view, a "jurisdictional hook" -interstate transactions-was insufficient alone to support the statute's constitutionality. Id.

78. Gibbs v. Babbitt, 214 F.3d 483, 487 (4th Cir. 2000), cert. denied sub nom. Gibbs v. Norton, 121 S. Ct. 1081 (2001).

79. 16 U.S.C. $\S 1532(19)$ (1994); 50 C.F.R. $\S 17.84(\mathrm{c})$ (2001) (making some exceptions when red wolves harm pets or livestock).

80. Brzonkala v. Va. Polytechnic Inst., 169 F.3d 820 (4th Cir. 1999) (en banc).

81. Gibbs, 214 F.3d at 491 (quoting Justice Kennedy's concurrence in United States v. Lopez, 514 U.S. 549, 574 (1995)). The judge who had authored the en banc VAWA decision dissented. See id. at 506 (Luttig, J., dissenting). As Judge Luttig explained, " The number of inferences (not even to mention the amount of speculation) necessary to discern in this activity a substantial effect on interstate commerce is exponentially greater than the number necessary in ... Morrison to show a substantial effect on interstate commerce from domestic assault." ld. at 507 .

82. Id. at 493 (majority opinion).

83. Id. at 494.

84. Id. at 497. Moreover, the regulation was a part of a larger picture, the Endangered Species Act, which is "a comprehensive and far-reaching piece of legislation that aims to conserve the health of our national environment." $I d$. 
Congress-not the courts-to weigh the value of removing wolves to protect commercial development against the value of restoring the species. Thus, the court rejected federalism pleas that land regulation and wildlife management were "traditional state functions." ${ }^{85}$ Endangering women is about family life, claimed to be the province of state law; endangering animals is potentially about commerce, and that potential suffices to sustain national laws, at least thus far at the circuit level. ${ }^{86}$

\section{The Commerce in and of Morals}

This foray into doctrine illustrates that, even with the new addendum of "economic in nature," choices abound about the reach of Commerce Clause powers. The current judicial effort to naturalize its conclusions by reference to activities "economic in nature" or "commercial in character" resembles the nineteenth-century equation of commerce with sales ${ }^{87}$ The issue is not whether commerce could be so circumscribed but rather why to draw this particular line. Given the import of the Commerce Clause holding in Morrison for constitutional law, the majority's discussion is cursory, lacking much by way of justification other than reductionist categorical stipulations.

Had the majority, in contrast, taken on a forthright exploration of Commerce Clause precedents, it would have been required to distinguish its frequent approval of the use of Commerce Clause powers to sustain social morals legislation-ranging from the many federal statutes reinforcing conventional status arrangements (such as the prohibition on possession of forms of pornography) to the more unusual ones altering entrenched practices (such as the 1960 s civil rights legislation). Indeed, the majority would have confronted not only repeated recognition of federal power but, upon occasion, the unapologetic use of Commerce Clause powers to "promote the general welfare, material and moral." ${ }^{88}$ For example, in early twentieth-century case law sustaining congressional regulation of liquor, lotteries, prostitution, and sexuality, the Court repeatedly upheld the propriety of national-level efforts (acknowledged to have " 'the quality of

85. Id. at 500 .

86. Other limitations may soon be imposed on Commerce Clause powers. See Solid Waste Agency v. U.S. Army Corps of Eng'rs, 531 U.S. 159 (2001) (avoiding the question of constitutionality by finding a regulation beyond statutory authority). Justice Stevens, joined by Justices Souter, Ginsburg, and Breyer, dissented, relying on Gibbs in part and distinguishing Morrison. Id. at 192-95 (Stevens, J., dissenting). On the other hand, given the attack on New York in the fall of 2001, the desire for national security will likely damp down interest in constraints on some aspects of federal power.

87. Justice Thomas has advocated returning to this conception. See United States v. Lopez, 514 U.S. 549, 584 (1995) (Thomas, J., concurring).

88. Hoke v. United States, 227 U.S. 308, 322 (1912). 
police regulations"" ${ }^{89}$ ) to exert social control. Mann Act prosecutions did not focus exclusively on the commerce in sex. Rather, a high percentage involved interracial couples, interstate adulterers, and breaches of promise to marry. ${ }^{90}$ The justification rested squarely on the national government's need to protect certain forms of family life_- " "the sure foundation of all that is stable and noble in our civilization." 91 Deciding in an era when Commerce Clause powers were read more narrowly than during the subsequent sixty years, the Court read Article I to permit police power policies aimed at suppressing activities seen as immoral so long as an interstate "hook" was available.

The Mann Act example cannot be cast aside as a relic of times past. In this era, when Commerce Clause powers are again being narrowed, the condemnation of certain forms of immorality continues to provide licensure for federal powers, as is exemplified by the Child Pornography and the Trafficking in Women Acts. Given these decades of rulings, the puzzle is why that umbrella did not suffice to shelter VAWA's civil remedy. VAWA could have been read as responsive to the threat to family life stemming from the immorality of hitting one's wife (and hence within the convention of federal social welfare legislation) or as an innovative gender equality provision, following the model of public accommodations laws (and hence within the convention of federal civil rights legislation). That a high volume of cases might have resulted has been proffered as the basis of some federal judges' objection to VAWA, ${ }^{92}$ but were plentitude alone the issue, the rationale would also topple pornography regulation.

89. Caminetti v. United States, 242 U.S. 470, 492 (1916) (quoting Hoke, 227 U.S. at 323).

90. See, e.g., David J. LANGUM, Crossing OVER the LINE: Legislating MORALITY AND THE MANN ACT 139-97 (1994).

91. Caminetti, 242 U.S. at 487 (quoting Murphy v. Ramsey, 114 U.S. 15, 45 (1885)). Murphy upheld a federal act providing that Utah voters could only be registered if legally qualified and that "no polygamist, bigamist, or any person cohabiting with more than one woman, and no woman cohabiting with any of the persons described ... shall be entitled to vote." Murphy, 114 U.S. at 28-29.

92. State and federal judges urged Congress not to enact the provision, relying in part on a "judicial impact statement" provided to the Judicial Conference of the United States that had warned of "as many as 53,800 civil tort cases annually," of which " $13,450 \ldots$ are anticipated to reach the Federal Courts." Violence Against Women: Victims of the System: Hearing on S. 15 Before the S. Comm. on the Judiciary, 102d Cong. 10, 15-16 (1991) (reprinting Violence Against Women Act of 1991, a judicial impact statement on S. 15 prepared by the Administrative Office of the U.S. Courts); see also Judith Resnik, The Programmatic Judiciary: Lobbying, Judging, and Invalidating the Violence Against Women Act, 74 S. CAL. L. REV. 269, 270-77 (2000) (detailing the initial opposition and then the subsequent decision by the Judicial Conference not to oppose the passage of the civil rights remedy).

The judicial impact statement's prediction proved wildly inaccurate. In the years between enactment and the Morrison decision, only about fifty cases were reported. Law Professors' Amici Brief, supra note 21 , at 14 (providing the data); see Jenny Rivera, A Promise Waiting To Be Fulfilled: The Violence Against Women Act of 1994 and the Construction of Multiple Consciousness in the Civil Rights and Feminist Movements, 4 J.L. \& POL'Y 463, 488 (1996) (criticizing VAWA's civil rights provisions as unlikely to be used by many of those eligible to do so because of a lack of the resources needed to pursue federal litigation). 
Explanation of the refusal to subsume VAWA within legitimate federal morals and civil rights legislation requires an appreciation of the stakes embedded in VAWA's civil rights remedy. It promised more than access to federal courts for the relatively few claimants seeking damages for gendermotivated violence. Had VAWA been sustained, federal legislative power would also have been available to redress other aspects of women's inequality. For example, as Justice O'Connor indicated at the Morrison oral argument, if the Court upheld VAWA's civil rights remedy, perhaps Congress could have the power to address discrimination in alimony payments made upon divorce. ${ }^{93}$ Federal laws might also have considered the question of compensation for home-based but currently unpaid "domestic" labor. Indeed, current federal pension law takes comparable concerns into account. The Employment Retirement Income Security Act (ERISA) allocates the wage-work benefits of pensions between spouses and protects divorced spouses in an effort to further equality norms; it is a species of marital property law. ${ }^{94}$ Similarly, the Family and Medical Leave Act, whose application to states has now been limited through Eleventh Amendment doctrine, ${ }^{95}$ had begun a conversation about the relationship between caregiving obligations and wage work. Commerce Clause powers could thus have been the basis for Congress to experiment with efforts to alter the gendered patterns of the economy, constituted by wage and nonwage work, inside and outside households. VAWA was but one aspect of the many possible exercises of federal power needed to achieve a categorical shift of women from dependent householders to physically secure equal citizens, able to partake of the full range of economic and political activities.

Those prospects proved intolerable for those intent on constraining national powers because they object to specific substantive policies and/or to the use of federal power to forward them. Keenly aware of the interdependencies of economic transactions and status, the search for a cap on "commerce" is a search to limit national lawmaking. The goal of reining in federal power is, of course, a reasonable political stance, but represents a choice between competing and contested views about the meaning of the United States Constitution. Through deployment of

93. See Transcript of Oral Argument, United States v. Morrison, 529 U.S. 598 (2000) (Nos. 99-5, 99-29), 2000 U.S. Trans. LEXIS 22, at *16.

94. 29 U.S.C. \& 1055 (1994) (mandating a qualified joint and survivor annuity for surviving spouses); id. $\$ 1056(\mathrm{~d})(3)(\mathrm{D})$ (permitting court orders that transfer pension benefits from a plan participant to a former spouse upon divorce).

95. Id. $\$ 2611$. The courts reason that, because the Act is gender-neutral and provides for leaves beyond those to care for children, Congress did not provide means congruent and proportional to an identifiable constitutional injury of gender discrimination and, therefore, that individuals cannot obtain monetary relief from state employers under the Act. See, e.g., Chittister v. Dep't of Cmty. Econ. Dev., 226 F.3d 223 (3d Cir. 2000); Sims v. Univ. of Cincinnati, 219 F.3d 559 (6th Cir. 2000). 
categorical federalism, however, the majority in Morrison neither provides an account of nor takes responsibility for its decision to stop federal legislation aimed at acknowledging female subordination inside households and the role that violence plays in economic citizenship.

In this discussion, I have deliberately linked VAWA, marking a progressive national effort to remake status relationships, with the history of federal statutes now seen by many as unattractive examples of social control. As Alexander Bickel explained, legislation like the Mann Act was inspired by "distinct strains of anti-urbanism, of xenophobia and opposition to continued large-scale immigration, and even of anti-Semitism." ${ }^{96}$ Both VAWA and the Mann Act are founded on a view of federal constitutional power that is expansive. Their juxtaposition underscores that deployment of federal power is not, however, inevitably wise. Both statutes augment state police powers. Both have the potential to displace conflicting state laws evidencing differing views on the moral, political, and economic status of women. I offer these examples (and more below) of the many varieties of federal social welfare legislation to remind readers that multi-faceted federalism is not a new word for a pro-national stance but rather an effort to shift the focus toward the many sources of political rightsmaking, all to be engaged critically as we make meaning of both "the federal" and of "women's rights."

\section{B. Working Moms, "Runaway Pappys," and Visiting Grandparents}

By categorizing violence against women as not "economic in nature" but related to family law and crime, the Morrison majority claimed a relationship between family, crime, and state government in which federal law could play no role. Critique is again available at two levels, first that the majority had choices when categorizing and erred, and second, that boxing itself into a choice was itself an error. For the first aspect of this analysis, I will share the majority's premise that VAWA was centrally related to family life.

VAWA symbolizes an understanding that violence within households, "domestic" in popular nomenclature, is a violation of "national" rights of adults to be equally safe within families. The power of the legislation should not be equated with the one provision struck in Morrison. The bulk of VAWA survives and thrives. In the years between 1994 and 1999, Congress provided $\$ 1.4$ billion to antiviolence programs, including $\$ 549$ million for services, training, officers, and prosecutors - "STOP" - to all fifty states; $\$ 21$ million for "safe houses" and law enforcement training;

96. ALEXANDER M. BICKEL \& BENNO C. SCHMidT, JR., THE JUdiCIARY AND RESPONSIBLE GOVERNMENT, 1910-1921, at 229 (1984). 
some $\$ 140$ million to facilitate arrests and prosecutions; $\$ 40$ million focused on rural domestic violence against women and children; and \$32 million in legal assistance and in grants for college campuses, community policing, and for help to children exposed to such violence. ${ }^{97}$ In the fall of 2000 , Congress reauthorized VAWA and provided yet more funds. ${ }^{98}$ VAWA also continues to facilitate the interstate enforcement of protection orders ${ }^{99}$ and to supply bases for criminal prosecutions of violators of certain of those orders. ${ }^{100}$ Federal law thus augments state work on the miseries of some families' lives, helps to provide shelter and counseling, supports state and tribal police and prosecutors, and brings needed dollars and attention to this arena. Arguably, even the defeat of the civil rights remedy has been productive. After Morrison, some municipalities and states have tried, in the words of the New York City Council, to fill the "void" left by the Supreme Court by enacting comparable provisions. ${ }^{101}$

97. 42 U.S.C. $\$ \$ 3796 \mathrm{gg}, 10409$ (a), 10416 (1994); Violence Against Women Act of 1999, Stalking Prevention and Victim Protection Act of 1999: Hearing Before the Subcomm. on Crime of the House Comm. on the Judiciary, 106th Cong. 22-37 (1999) [hereinafter 1999 VAWA Hearings] (statement of Bonnie Campbell, Director of the Department of Justice's Violence Against Women Office).

98. The Violence Against Women Act of 2000, Pub. L. No. 106-386, 114 Stat. 1491 (codified in scattered sections of 42 U.S.C.); 2000 Legislative Summary: Anti-Crime Package, 58 CQ WKLY. 2914 (2000) (describing the authorizations of almost $\$ 3.3$ billion for grants, including $\$ 185$ million a year for five years for state programs to coordinate victim advocates, police, and prosecutors, $\$ 175$ million a year for five years for shelters for battered women and children, $\$ 40$ million for a new program providing legal assistance to battered women, and $\$ 25$ million for a new program to assist women in obtaining transitional housing).

99. 18 U.S.C. $\$ 2265$ (1994).

100. Id. $\$ 2262$ (prohibiting the crossing of a state line with the intent to engage in or actual engagement in conduct that violates a protective order). This provision was upheld in United States v. Wright, 128 F.3d 1274 (8th Cir. 1997), and United States v. Casciano, 124 F.3d 106 (2d Cir. 1997). Also authorized is prosecution if a defendant crosses a state line with the intent to commit or in the act of committing a crime of domestic violence. 18 U.S.C. $\$ 2261$. This provision was upheld in United States v. Gluzman, 154 F.3d 49 (2d Cir. 1998), cert. denied, 526 U.S. 1020 (1999). As of 1999, more than 170 prosecutions had been pursued. 1999 VAWA Hearings, supra note 97, at 32-33 (statement of Bonnie Campbell, Director of the Department of Justice's Violence Against Women Office). In 2000, more than 230 criminal cases were filed under the various criminal provisions of VAWA. Executive Office for U.S. Attomeys, U.S. Dep't of Justice, Criminal Caseload Statistics, Violence Against Women (2001) (on file with author).

101. E.g., NEW YORK CITY, N.Y., ADMIN. CODE tit. 8, $\$ \$ 8-901$ to -905 (2001) (providing a civil cause of action for any person committing a "crime of violence motivated by gender" and authorizing compensatory and punitive damages, injunctions, and fees). The Act addresses "crime[s] of violence committed because of gender or on the basis of gender, and due, at least in part, to an animus based on the victim's gender" but not "random acts of violence unrelated to gender or . . . acts that cannot be demonstrated, by preponderance of the evidence, to be motivated by gender." Id. Parallel provisions have been proposed in other municipalities, as well as in the states of Arkansas, Arizona, Illinois, and New York. E.g., S.B. 1550, 45th Leg., 1st Reg. Sess. (Ariz. 2001) (providing damage actions when acts of violence are "motivated by gender," as established by a "preponderance of the evidence," but not if "random"); The Arkansas Violence Against Women Act of 2001, H.B. 1691, 83d Gen. Assem., Reg. Sess. (Ark. 2001) (providing for protection of the "civil rights of victims of gender motivated violence and ... promot[ing] the public safety, health, and activities by establishing a state civil rights cause of action"); Gender Violence Act, H.B. 3279, 92d Gen. Assem. (Ill. 2001) (providing that because "[e]xisting State and federal laws do not adequately prevent and remedy gender-related violence, such as domestic 
Let us thus call VAWA a regulation of the family (or more appropriately, of dissolving or disabled families) and applaud it. But, in contrast to the Morrison majority's proffered logic (if a law is "about families," then it is beyond the authority of Congress), placing a law within that category does not preclude federal legislation. In fact, upon entering the categorical box of the family, one finds a great deal of federal law inside.

\section{Federal Laws of the Family}

That federal law should speak substantively about, impose requirements upon, and offer protection to family life is an artifact of this country's founding, expressed periodically during the nineteenth century through federal legislation using marriage policy to limit polygamy, to establish rights of freed slaves, and to distance Indian tribal members from their communities. ${ }^{102}$ During the twentieth century, action on this federal front (like many others) expanded. Interest in developing federal family law stemmed from several factors including an increasingly mobile population, economic crises clarifying the relationship between individual circumstances of poverty and national markets, waves of immigration, and comparative data that the United States lagged behind other nations in addressing infant mortality and children's health. ${ }^{103}$ As a consequence, contemporary federal family law is a mélange of national norms aimed at affirming certain conceptions about how families are constituted, what

violence, which is disproportionately visited upon women by men; sexual abuse, which harms many women and children without being reported or prosecuted; and violence against men and women for actual or attributed sexual or gender nonconformity," persons subjected to such sex discrimination have civil causes of action for monetary and equitable relief); The Gender Violence Act, H.B. 4407, 91 st Gen. Assem., Reg. Sess. (Ill. 2000); An Act To Amend the Civil Rights Law, in Relation to Providing a Civil Remedy for Victims of Bias-Related Violence or Intimidation, S.B. 2776, 224th Leg., Reg. Sess. (N.Y. 2001) (providing remedies for injuries based on gender and sexual orientation and authorizing civil suits to be brought by both the attomey general and individuals).

102. See Nancy CotT, PUblic Vows: A History of Marriage and the Nation 9-23, 115-31 (2000); PEGGY COOPER DAVIS, NEGLECTED STORIES: THE CONSTITUTION AND FAMILY VALUES (1997); Katherine M. Franke, Becoming a Citizen: Reconstruction Era Regulation of African American Marriages, 11 YALE J.L. \& HUMAN. 251 (1999); Jill Elaine Hasday, Federalism and the Family Reconstructed, 45 UCLA L. REV. 1297 (1998); Judith Resnik, Dependent Sovereigns: Indian Tribes, States, and the Federal Courts, 56 U. CHI. L. REV. 671 (1989).

103. An increasingly rich literature analyzes the effects of social policy on gender and gender's role in shaping policy. Several scholars address the period of interest here. E.g., ALICE KESSLER-HARRIS, IN PURSUIT OF EQUITY: WOMEN, MEN, AND THE QUEST FOR ECONOMIC

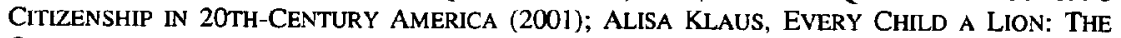
ORIGINS OF MATERnal and INFANT HEALTH POLICY IN THE UNITED STATES aNd FRANCE, 1890. 1920 (1993); SUZANNE METTLER, DIVIDING CITIZENS: GENDER AND FEDERALISM IN NEW Deal Public Policy (1998); Theda SKocPol, Protecting Soldiers and Mothers: THE POLITICAL ORIGINS OF SOCIAL POLICY IN THE UNITED STATES 7-55 (1992); Katharine T. Bartlett, Feminism and Family Law, 33 FAM. L.Q. 473 (1999). 
relationships within families have primacy, and the material consequences of family life.

The legal routes to federal family lawmaking are-like federalism itself-premised on a range of constitutional provisions including the Commerce and Spending Clauses, the Full Faith and Credit Clause, and the Fourteenth Amendment. ${ }^{104} \mathrm{~A}$ brief sketch of some statutes and constitutional law that create substantive federal family law policies exemplifies the breadth. Federal tax law defines family units and creates economic incentives for members. ${ }^{105}$ Social security law endows wagework with the power of enabling subsequent retirement benefits but treats domestic production and reproduction differently. ${ }^{106}$ Although state law initially organizes assets between divorcing couples, "federal bankruptcy law radically alters all the financial obligations created by state law." 107 Immigration law gives meaning to the act of marriage, ${ }^{108}$ and the Defense of Marriage Act defines it for purposes of federal law and interstate obligations. ${ }^{109}$ ERISA creates federal marital property law in pensions that

104. See Ann Laquer Estin, Shared Governance: Family Law in Congress and the States (Jan. 3,2001 ) (unpublished manuscript, on file with author) (detailing the constitutional bases Congress has relied on since 1974 to enact legislation aimed at family life, specifically spending powers for many federal programs and regulations relating to child support, welfare, adoption, foster care, and medical care; commerce powers for VAWA, child-support recovery legislation, abortion clinic access statutes, parental kidnapping provisions, and prohibitions on discrimination based on pregnancy; full faith and credit for child custody, support, and marriage legislation; and the Fourteenth Amendment, also for VAWA, for transracial adoption legislation, and for proposed but not enacted legislation on parental rights and freedoms).

105. See, e.g., 26 U.S.C. § 2(b) (1994) (defining "head of a household" for tax purposes); id. $\$ 7701$ (a)(17) (defining husband and wife). Boris Bittker is one of the first within the legal academy to have understood the role of tax law in family life. See Boris Bittker, Federal Income Taxation and the Family, 27 STAN. L. REV. 1389 (1975). Today, an extensive literature addresses the effects of gender on the tax code and the tax code's effects on gender. See, e.g., EDWARD J. MCCAFFERY, TAXING WOMEN (1997); NADA EISSA \& HILARY Williamson HoYNes, The EARNED INCOME TAX CREDIT AND THE LABOR SUPPLY OF MARRIED COUPLES (Nat'l Bureau of Econ. Research, Working Paper No. 6856, 1998).

106. See Mary E. Becker, Obscuring the Struggle: Sex Discrimination, Social Security, and Stone, Seidman, Sunstein \& Tushnet's Constitutional Law, 89 COLUM. L. REV. 264 (1989).

107. Teresa A. Sullivan, Elizabeth Warren \& Jay Lawrence Westbrook, The Fragile Middle Class 175 (2000) [hereinafter Sullivan ET AL., THE Fragile MidDle ClASSI; see also TERESA A. SUllivan, ElIZABETH WARREN \& JAY LAWRENCE WESTBROOK, AS WE FORGIVE OUR DEBTORS: BANKRUPTCY AND CONSUMER CREDIT IN AMERICA 149-59 (1989) (examining federal bankruptcy law's effect on women filing singly). How bankruptcy should treat child support debt is the subject of intense debate. Compare 11 U.S.C. $\$$ 523(a)(5) (1994) (not excusing debtors from child support and alimony debt), with Bankruptcy Abuse Prevention and Consumer Protection Act of 2001, H.R. 333, 107th Cong. \$§ 211-220 (2001) (proposing a change).

108. Nguyen v. INS, $121 \mathrm{~S}$. Ct. 2053 (2001) (upholding the constitutionality of a statute that drew a distinction in terms of citizenship opportunities between the children of unwed fathers and the children of unwed mothers); see also Asylum and Withholding Definitions, 65 Fed. Reg. 76,588 (proposed Dec. 7, 2000) (to be codified at 8 C.F.R. pt. 208) (addressing domestic abuse and political asylum).

109. Defense of Marriage Act of 1996, Pub. L. No. 104-199, § 3(a), 110 Stat. 2419, 2419 (codified at 1 U.S.C. $\S 7$ (Supp. V 1999)) (defining "marriage" as between one "man" and one "woman" for "determining the meaning of any Act of Congress, or of any ruling, regulation, or 
trumps state property laws. ${ }^{110}$ In short, a variety of familiar areas of federal law intersect with and regulate aspects of family life.

\section{Supporting Children}

Categoricalists define the care and economic support of children as within the core of family law. I have therefore chosen it as an aspect of federal family law to mine in more detail. Governments can facilitate parental provision of care by a variety of methods, such as paying parents to provide care to children, subsidizing care outside of homes, supplying food and health benefits, and requiring employers to provide release time from work. The choice of policy sustains or alters assumptions about the parental roles and earning potentials of women and men. Further, given cultural, religious, and ethnic variations in family patterns, governments also have decisions to make about which individuals to recognize as constituting a "family." 111 Thus, when governments impose obligations of child support, their rules either reaffirm or disrupt extant understandings of family constellations and gendered allocations of labor.

That state laws make such decisions is common ground. What the Morrison majority ignored is that federal law also makes such decisions. Federal social welfare legislation, sometimes assumed to have begun with the 1935 Social Security Act, in fact was launched decades earlier, as Theda Skocpol documents in her history of pensions provided for civil war veterans and for mothers. Skocpol's titular delineation in Protecting Soldiers and Mothers neatly encapsulates the prevailing gendered assumptions, reinforced in part by what she terms "maternalist" social policy. ${ }^{112}$ Prompted by women's organizations seeking to reduce infant mortality rates, the federal government created the Home Education Division of the U.S. Bureau of Education in 1911, the Children's Bureau in

\footnotetext{
interpretation of the various administrative bureaus and agencies of the United States"); id. § 2(a) (codified at 28 U.S.C. $\$ 1738 \mathrm{C}$ ) (eliminating from the full faith and credit requirement the recognition of same-sex relationships, entered into under the laws of one state, by other states). Many commentators have addressed the legislation. See, e.g., Jennifer Gerarda Brown, Competitive Federalism and the Legislative Incentives To Recognize Same-Sex Marriage, $68 \mathrm{~S}$. CAL. L. REv. 745 (1995); Andrew Koppelman, Same-Sex Marriage, Choice of Law, and Public Policy, 76 TEX. L. REV. 921 (1998).

110. 29 U.S.C. § 1055 (1994); id. § 1056(d)(3)(D); Boggs v. Boggs, 520 U.S. 833 (1997) (holding that these provisions preempt conflicting state community property rules).

111. See, e.g., WOMEN, THE FAMILY, AND POLICY (Esther Ngan-ling Chow \& Catherine White Berheide eds., 1994).

112. SKOCPOL, supra note 103, at 525-39. Linda Gordon agrees, but then asks why such programs "designed by feminists [were] so bad for women and children." LINDA GORDON, PITIED BUT NOT ENTITLED: SINGLE MOTHERS AND THE HISTORY OF WELFARE 1890-1935, at $289-93$ (1994) (discussing the "family-wage system," then supported by welfare reformists, which limited possibilities for alterations in social ordering that would have been more generative for women of all classes and races).
} 
1912, and the Women's Bureau in $1918,{ }^{113}$ to provide "information, investigation, and publicity." ${ }^{114}$ By 1921, through the Federal Act for the Promotion of the Welfare and Hygiene of Maternity and Infancy (the Sheppard-Towner Act, in force until 1929), federal funding provided more than a million dollars to the Children's Bureau to disperse to cooperating states for family care. ${ }^{115}$

During the following seventy years of federal lawmaking, substantive policies reflected and reinforced gendered assumptions about parental responsibilities. Aid to (Families with) Dependent Children, a program begun during the first half of the twentieth century, represented a federal policy that mothers who lacked their own income or that of spouses should be able to stay at home to care for children. Welfare legislation in 1996 illustrates a different federal policy: that such women should be prepared to entrust their children to others and demonstrate their commitment to gaining market employment. ${ }^{116}$

Attitudes toward the roles fathers should play-in terms of both support and care-have also shifted over the century. ${ }^{117}$ As Linda Gordon explains, in 1900 and in 1960 , more than $85 \%$ of children lived with two parents. ${ }^{118}$ Furthermore, "from the late nineteenth century until the 1930s, in all classes, races, and ethnic groups, most single mothers were widows"$77 \% .{ }^{119}$ By the 1930s, however, the proportion of single widowed mothers had fallen to under $55 \% .{ }^{120}$ Men had left households but, with divorce generally uncommon, desertion was the description.

The issue was what obligations these men had to those left behind. In the 1930s and 1940s, state laws did not offer uniform answers on which adult members of families were obligated to support children of what

113. SKOCPOL, supra note 103 , at $304,374,480-81$.

114. 43 CONG. REC. 2897 (1909) (statement of Rep. Herbert Parsons); see also id. at 2905 (cxplaining the federal role as "an aid" to states, not a "supplanter" of them).

115. SKOCPOL, supra note 103 , at 481 . See generally KLAUS, supra note 103 , at $208-43$ (describing the Children's Bureau during that time). When that statute was attacked as beyond federal authority, the Supreme Court declined to address that claim on the ground that Massachusetts lacked standing to bring it. Massachusetts v. Mellon, 262 U.S. 447 (1923); see also Richard A. Epstein, Standing and Spending-The Role of Legal and Equitable Principles, 4 CHAP. L. REV. 1 (2001) (urging revisiting of both issues).

116. Personal Responsibility and Work Opportunity Reconciliation Act of 1996, Pub. L. No. 104-193, § 103(a)(1), 110 Stat. 2105, 2129 (codified at 42 U.S.C. $\$ 607(\mathrm{e})(2)$, (g) (Supp. V 1999)) ("It is the sense of the Congress that ... each State ... assign the highest priority to requiring adults in 2-parent families and adults in single-parent families that include older preschool or school-age children to be engaged in work activities.").

117. See generally David L. Chambers, Fathers, the Welfare System, and the Virtues and Perils of Child-Support Enforcement, 81 VA. L. REV. 2575, 2583-88 (1995) (discussing the enforcement of child support).

118. GORDON, supra note 112 , at 18 (stating that $9 \%$ of children lived with one parent in 1900 and $9.1 \%$ did so in 1960 ).

119. Id. at 19.

120. Id. at 20. 
ages $^{121}$ and whether to pursue violators civilly or sanction them criminally. ${ }^{122}$ The variation became a subject of discussion among state leaders, who attempted to create uniform laws ${ }^{123}$ but found themselves unable to lower the costs of pursuit or to sustain interest in pursuit from prosecutors in states distant from the particular families in need. ${ }^{124}$ Additional hurdles came from state courts unwilling to hold that judgments for future payments from another state were enforceable under full faith and credit requirements. ${ }^{125}$

With the creation in the 1930s of federal welfare benefits for needy children came federal interest in ensuring that adult family members who had the resources to pay child support did so. ${ }^{126}$ The development of federal policy stemmed from substantive visions about who constituted families, about which adults had obligations to children, and about how to spend tax dollars wisely. Federal family policy reflected gender-conventional roles rather than attempting to alter norms of masculinity by promoting fathers as

121. For example, in some states, mothers-who, if married, had no rights to property - did not have support obligations. See HARRY D. KRAUSE, CHILD SUPPORT IN AMERICA 4 n.9 (1981) (quoting a 1979 Illinois case noting the " untraditional idea that the mother, as well as the fathereven where she is a noncustodial parent-may be obliged to contribute to the support of the minor children"). States also had diverse rules on the obligations of step-parents and other relatives toward children and on adult children's obligations toward parents. Id. at 38-44.

122. See id. at ix (noting that the 1934 American Law Institute's Restatement of Conflict of Laws described child support as "of no special interest to other states" because such obligations were not enforceable elsewhere).

123. New York State developed a prototype. See Uniform Support of Dependents Law, ch. 807,1949 N.Y. Laws 1801 (repealed 1997). See generally WILLIAM J. BROCKELBANK, INTERSTATE ENFORCEMENT OF FAMILY SUPPORT (THE RUNAWAY PAPPY ACT) (1960) (discussing the Uniform Reciprocal Enforcement of Support Act). The statute was replaced by the Uniform Interstate Family Support Act, N.Y. JUD. CT. ACTS $\$ \$ 580-101$ to -901 (McKinney 1999). This revision was prompted in turn by the 1996 welfare reforms, discussed infra note 131 .

124. One issue was the ability to obtain personal jurisdiction over the alleged offender; federal law did not recognize jurisdiction without physical contact (real or constructive) until International Shoe Co. v. Washington, 326 U.S. 310 (1945). Writing after International Shoe and after California's enactment of the Uniform Reciprocal Enforcement of Support Act in 1951, Albert Ehrenzweig explored yet other problems, including which state law applied, what enforcement mechanisms such as contempt could be applied to enforce obligations, and how to treat support orders subject to modification. See Albert A. Ehrenzweig, Interstate Recognition of Support Duties: The Reciprocal Enforcement Act in California, 42 CAL. L. REV. 382 (1954).

125. See Sistare v. Sistare, 218 U.S. 1 (1910) (holding that past-due alimony payments were entitled to full faith and credit only if not subject, under the issuing state's law, to retroactive modification); see also Barber v. Barber, 323 U.S. 77, 86-87 (1944) (Jackson, J., concurring) (challenging the relevance of finality to enforcement through full faith and credit). Justice Jackson also wrote an essay arguing that national legislation should integrate legal systems, as it was doing for the economy and social welfare. Robert H. Jackson, Full Faith and Credit-The Lawyers' Clause of the Constitution, 45 COLUM. L. REV. 1 (1945). Enforcement remained difficult in the subsequent decades. See Duncan J. Stewart, Note, Domestic Relations: Interstate Enforcement of Support Orders: Necessity and Feasibility of Federal Legislation, 48 CORNELL L.Q. 541 (1963).

126. Contemporary federal interest in child support enforcement remains linked to welfare support. See 144 CONG. REC. S5734 (daily ed. June 5, 1998) (statement of Sen. Herbert Kohl) (supporting the 1998 amendments to the Child Support Recovery Act by noting that "[i]t has been estimated that if delinquent parents fully paid up their child support, approximately 800,000 women and children could be taken off the welfare rolls"). 
care providers. Fathers were identified as the primary wage earners; mothers were situated as caregivers. For example, a 1932 federal law, permitting only one person within a household to be in federal employ, embedded the concept of the "family wage." The presumption of the man as a family's wage earner can be seen from the fact that almost all of the 1500 people fired during the law's first year were women. ${ }^{127}$

Federal involvement in child support increased as federal dollars went toward support of children and as state actors sought help in enforcement of their collection laws. Initially, federal statutes focused on encouraging and assisting state collection of child support from wayward fathers. Subsequent federal regulation sought to take direct action against adults liable for support, ${ }^{128}$ resulting in what some have termed "the federalization of child support enforcement." ${ }^{29}$ Through laws passed in 1968, 1974, 1984, 1988, and 1996, Congress created a federal locator system and imposed federal standards on how to search for absent fathers, how to recoup funds from them, and how to assess how much to recoup from them. ${ }^{130}$ The 1996 Act mandated adoption of uniform state laws on child support as a condition of federal funds, resulting in state enactments that march to a federal drum. ${ }^{131}$ In terms of the content of federal policy, Gwendolyn Mink describes the 1996 legislation as representing a bipartisan agreement that "poor women

127. CoTT, supra note 102, at 173 (discussing section 213 of the Economy Act of 1932, repealed some five years later); see also ALICE KESSLER-HARRIS, A WOMAN'S WAGE: Historical MEANINGS AND SOCIAL CONSEQUENCES 57-80 (1990) (exploring the gendered meanings of family "providers").

128. Chambers, supra note 117 , at 2583-84.

129. KRAUSE, supra note 121, at 307-11 (discussing the creation in 1975 of the Office of Child Support Enforcement (OCSE) in the Department of Health, Education, and Welfare); Ann Laquer Estin, Federalism and Child Support, 5 VA. J. SOC. POL'Y \& L. 541, 545 (1998).

130. Legislation enacted in 1965 and 1967 authorized agencies of the federal government (such as the Internal Revenue Service) to provide states with addresses of absent parents. Social Security Amendments of 1965, Pub. L. No. 89-97, $\S 340,79$ Stat. 286, 411 (codified as amended at 42 U.S.C. $\$ 1306$ (1994)); Social Security Amendments of 1967, Pub. L. No. 90-248, § 211, 81 Stat. 821, 896-97 (1968) (codified as amended at 42 U.S.C. \& 622). Subsequent amendments expanded the obligations of states and the oversight role of the federal government. Family Support Act, Title IV-D of the Social Security Act of 1974, Pub. L. No. 93-647, 88 Stat. 2351 (1975) (codified at 42 U.S.C. $\$ \S 651-660$ ); Child Support Enforcement Amendments of 1984, Pub. L. No. 98-378, 98 Stat. 1306 (codified at 42 U.S.C. \$§ 666-667); Family Support Act of 1988, Pub. L. No. 100-485, 102 Stat. 2408 (codified at 42 U.S.C. $\$ \S 617,668-669,681-687$, 1396r-6). Revisions of those provisions came through the Personal Responsibility and Work Opportunity Reconciliation Act of 1996, Pub. L. No. 104-193, 110 Stat. 2105 (codified in scattered sections of 42 U.S.C. (1994 \& Supp. V 1999)), which requires participating states to establish paternity and to enforce child support obligations by deducting payments when a custodial parent refuses cooperation. For discussion of the evolution of laws and practices, see generally CHILD SUPPORT: THE NEXT FRONTIER (J. Thomas Oldham \& Marygold S. Melli eds., 2000); and Estin, supra note 129.

131. Specifically, 42 U.S.C. $\& 666$ conditions the receipt of federal funds on state efforts to locate absent parents and details the procedures that need to be in force. Simons, supra note 62 , at 940-41 n.211 (describing the effects of the federal legislation on state lawmaking). 
with children should at least be financially tied to their children's biological fathers, or better yet, be married to them." 132

Federal criminal law can also be a vehicle for national norms. During and after World War II, federal legislators began to consider what became known as the "Runaway Pappy Act" - a version of which was championed in the late 1940 s by then-Representative Gerald Ford ${ }^{133}$ Proponents sought to craft a federal crime based upon a father's willful departure from a state to avoid child support obligations. ${ }^{134}$ They argued for federal lawmaking because (1) during World War II, the federal government had contributed to the problem by encouraging fathers to leave their households to work in factories or to go to war; (2) state laws varied, and interstate enforcement was expensive and sometimes unavailing; and (3) by moving from state to state, fathers could avoid obligations of support. ${ }^{135}$ Some of the proposals would have permitted direct prosecution and imposed criminal penalties, while others sought to deploy the federal courts as a registry for interstate support orders and therefore as a means of enforcement for moneys due. In the legislative records of the many bills, proponents did not evidence concern about the constitutional vulnerability of their proposals. Long before the 1960s interpretations of Commerce Clause powers, members of Congress assumed that obligations for child support had a sufficient nexus to the economy to support federal legislation, ${ }^{136}$ which was welcomed by state officials seeking federal assistance. ${ }^{137}$

132. Gwendolyn Mink, Violating Women: Rights Abuses in the Welfare Police State, 577 ANNALS AM. ACAD. POL. \& SOC. SCI. 79, 80 (2001); see also Sullivan ET AL., THE FRAGILE MIDDLE CLASS, supra note 107, at 174 (discussing how marriage permits coinsurance by partners and how "the trilogy of marriage, divorce, and no remarriage... correlate[s] with financial ruin").

133. H.R. 1538, 81 st Cong. (1949). Senator Arthur Capper of Kansas first proposed such a bill in 1941 and twice thereafter. See S. 1265, 77th Cong. (1941); S. 761, 78th Cong. (1943); S. 453, 79th Cong. (1945).

134. See, e.g., S. 1265 \& 2(a). The bill proposed that:

Any person being subject to a judgment or decree of a court of any State for the support of his or her minor children, any part or installment of which is due or unpaid, who shall, without first reporting to the court entering such judgment or decree . . . transfer or remove his or her residence from such State with the intent to avoid payment of such judgment, shall be guilty of a crime against the United States.

135. See, e.g., Making Abandonment of Dependents a Federal Crime: Hearings Before Subcomm. No. 2 of the House Comm. on the Judiciary, 81 st Cong. (1949-1950) [hereinafter 19491950 Abandonment Hearings].

136. Little in the legislative hearings addressed the issue. The Chair of the House Subcommittee, Sam Hobbs, directed a witness by commenting, "What we are interested in is not so much the question of the jurisdiction of the Federal Government. We recognized that in the Lindbergh Act, in the Mann Act, and in the more recent developments along that line." Id. at 37. The Department of Justice also advised that the "instant measure is probably constitutional by virtue of" the Commerce Clause. Id. at 117 (reproducing Letter from the Office of the Assistant to the Attomey General, Department of Justice to Emanuel Celler, Chairman, House Committee on the Judiciary (July 1, 1949)).

137. For example, the Council of State Government and the State of Indiana endorsed the 1949 bill proposed by Representatives Ford and Jacobs. See id. at 9 (statement of Rep. Andrew Jacobs). State attorneys general remained supportive of federal action, as commentary in the 
As is familiar to those who focus on either family law or federal jurisdiction, the criminal legislation (the Child Support Recovery Act of 1992, or CSRA) ${ }^{138}$ became law decades later, by which time "runaway pappys" had became "deadbeat dads." 139 Together, whether wisely or not, ${ }^{140}$ both civil and criminal federal statutes focus on collecting child support payments from fathers. Less familiar is that major opposition to the deployment of federal legal resources for these efforts came from the federal judiciary itself. ${ }^{141}$ At first, objections came through commentary from the official voice of the Article III judiciary. Between 1958 and 1992, the Judicial Conference opposed all of the many proposals for federal jurisdiction for either the registration in federal court of support orders or criminal sanctions. ${ }^{142}$ The Conference argued that the various bills were ill-

1980s from Connecticut's then-Attorney General indicated. See JOSEPH I. LIEBERMAN, ChILD SUPPORT IN AMERICA 91 (1986) (praising the effectiveness of federal child support legislation).

138. 18 U.S.C. $\$ 228$ (1994). This Act was amended by the Deadbeat Parents Punishment Act of 1998, Pub. L. No. 105-187, 112 Stat. 618; see supra note 60 for its provisions and notes 64-65 and 70-72 for litigation about its constitutionality. Earlier versions included H.R. 1, 92d Cong. (1972), which would have amended the Social Security Act to make a federal crime of the failure by any parent "under a legal duty to provide for the support" not to pay if the "child ... receive[s] assistance payments ... funded ... in part . . . by the Federal Government." S. REP. NO. 92-1230, at 859 (1972).

139. See Mary Jo White, Collecting Child Support Is a Federal Matter, N.Y. TIMES, Aug. 14, 1995, at A15 (discussing, in her capacity as United States Attorney for the Southem District of New York, the arrest of a "deadbeat dad" in Vermont on charges of owing in excess of $\$ 500,000$ in child support). In 2000, some 450 cases were filed nationwide. Executive Office for U.S. Attomeys, U.S. Dep't of Justice, Criminal Caseload Statistics, All Child Support Recovery Act (2001) (on file with author).

140. See, e.g., Chambers, supra note 117, at 2584, 2588-605; id. at 2588 (noting that "more fathers pay more money than ever before, but half of all children with an absent parent still receive no support"). Chambers argued that these obligations might prompt the poorest fathers to avoid relationships with their children, and that some children would be better served if they had no relationship with fathers who were abusive to either the custodial parent or the child. Id. at 2602-05; see also Susan Notar \& Vicki Turetsky, Models for Safe Child Support Enforcement, 8 J. GENDER SOC. POL'Y \& L. 657 (2000) (exploring how child support enforcement policies reduce the safety of both women and children); GORDON, supra note 112 (criticizing the focus on privatization of support for reinforcing hierarchies based on gender, race, and class and thus reiterating political stratification and supporting state-provided minimums or universal programs); ROBERT I. LERMAN \& ELAINE SORENSEN, CHILD SUPPORT: INTERACTIONS BETWEEN PRIVATE AND PUBliC TRanSFERS 12 (Nat'l Bureau of Econ. Research, Working Paper No. 8199, 2001) (arguing that legal child support obligations are more efficient when custodial parents live together since when parents are apart, the noncustodial parent has less control, prompting a decline in investments).

141. The Department of Justice, on behalf of the FBI, also raised objections about the deployment of federal resources for this problem. See, e.g., 1949-1950 Abandonment Hearings, supra note 135, at 36 (statement of Rep. John A. Carroll) (addressing the need to convince the FBI of the propriety of such federal legislation).

142. See 1957 ANNUAl RePort OF tHE PROCEedings of the Judicial Conference of THE UNITED STATES 37; 1959 ANNUAL REPORT OF THE PROCEEDINGS OF THE JUDICIAL CONFERENCE OF THE United States 35, 316-17; 1963 RePORTS OF THE PROCEedings OF tHe Judicial CONFERENCE of THE UNITED STATES 73; 1965 REPORTS OF THE PROCEEDINGS OF THE JUdiCIAL CONFERENCE OF THE UNITED STATES 17, 63; 1967 REPORTS OF THE PROCEEDINGS OF THE JUdicial CONFERENCE OF THE UNITED STATES 21, 68-69; 1971 REPORTS OF THE PROCEEDINGS OF THE JUDICIAL CONFERENCE OF THE UNITED STATES 80; 1977 REPORTS OF THE 
advised, a misuse of federal power in matters that would be best left to the states. (In contrast, the Conference has often declined to comment on proposed bills on the ground that such issues were matters of "legislative policy." $)^{143}$ Subsequently, the Supreme Court has registered its objections to federal court involvement in family life in other forms, such as by declining to interpret legislation to endow individuals with rights of enforcement ${ }^{144}$ and by imposing restrictions on jurisdictional provisions that could have enabled litigants to file family-related claims in federal court. ${ }^{145}$ Most recently and vividly, as in Morrison, judges have held that Congress has no power to vest certain matters in federal courts. ${ }^{146}$

These exchanges represent a long history of the judiciary and Congress debating - and disagreeing about - the shape of federal family-law policies and particularly about whether Congress could or should enlist the federal courts in implementing its laws. ${ }^{147}$ Such debates are themselves further

PROCEEDINGS OF THE JUDICIAL CONFERENCE OF THE UNITED STATES 53; 1992 REPORTS OF THE PROCEEDINGS OF THE JUdiCIAL CONFERENCE OF THE UNITED STATES 57. Similarly, the Judicial Conference initially objected to enactment of the civil rights remedy in VAWA. See Resnik, supra note 92 , at 271-72.

143. For examples, see Judith Resnik, Trial as Error, Jurisdiction as Injury: Transforming the Meaning of Article III, 113 HARV. L. REV. 924, 961-67 (2000).

144. Blessing v. Freestone, 520 U.S. 329 (1996); Suter v. Artist, 503 U.S. 347 (1992); Thompson v. Thompson, 484 U.S. 174 (1988). See generally Anne B. Goldstein, The Tragedy of the Interstate Child: A Critical Reexamination of the Uniform Child Custody Jurisdiction Act and the Parental Kidnaping Prevention Act, 25 U.C. DAvIS L. REV. 845 (1992) (discussing the intractability in a federated system of the problem generated by conflicting laws on child custody, and criticizing statutory and judicial responses).

145. See, e.g. Ankenbrandt v. Richards, 504 U.S. 689 (1992) (holding that the federal courts do have jurisdiction for alleged abuses of children by a father and his female companion but reading the diversity jurisdiction statute, 28 U.S.C. $\$ 1332$ (1994), as incorporating a "domestic relations exception" for cases involving divorce, child custody, and alimony); Lehman $v$. Lycoming County Children's Servs. Agency, 458 U.S. 502 (1982) (holding that the habeas statutes, 28 U.S.C. $\$ \$ 2241-2254$, cannot be used to challenge a state law under which parents lost custody); Moore v. Sims, 442 U.S. 415 (1979) (requiring abstention when pending state proceedings were underway); Martin Guggenheim, State Intervention in the Family: Making a Federal Case Out of It, 45 OHIO ST. L.J. 399 (1984) (detailing the use of procedural doctrine to bar "access to federal courts on issues of child protection"). When an issue is about "family" and when a constitutional question dominates is itself an interesting example of shifting forms of categorization. See, e.g., Moore v. City of East Cleveland, 431 U.S. 494 (1977) (stating that had the issue been only one of "zoning," local law might have had precedence but because the question also implicated claimed discrimination against family clusters, federal constitutional norms applied).

146. This jurisprudence protects the dockets of federal courts but is often justified as protecting states from federal "intervention." Unless, as some advocate, the constriction of Commerce Clause powers is followed by a parallel retreat on Spending Clause authority, Congress retains power to frame programs that could be seen as more "intrusive" on states than are commerce-based federal causes of action such as that struck in Morrison. See Estin, supra note 104.

147. Elsewhere, I have explored the legitimacy of the federal judiciary having any such collective view at the nonconstitutional level and its effects on constitutional interpretation. Resnik, supra note 92, at 276-80. Other commentators question the wisdom of the particular federal policies crafted. See, e.g., Naomi R. Cahn, Children's Interests in a Familial Context: Poverty, Foster Care, and Adoption, 60 OHIO ST. L.J. 1189 (1999); Sylvia Law, Families and Federalism, 4 WASH. U. J.L. \& POL'Y 175 (2000); sources cited supra note 140. 
testaments that federal statutory family policies are plentiful and wellknown to federal judges. Through a range of civil and criminal statutes enacted under Spending and Commerce Clause powers, Congress has developed a regulatory regime reflecting substantive decisions about family policy, only some of which involve rights of action in federal court. Within the category of the family can be found federal regulation, and within the category of the federal can be found rules of family life.

\section{Superintending States}

Morrison might be read as signaling more-that all such legislation will soon fall because it invades the "truly local" province of the family. But Congress is not the only source of federal law relating to family life. When one turns from statutes to the Constitution, one finds that the federal judiciary is itself a font of federal family lawmaking.

The word "family" does not itself appear in the Constitution. The concept is only mentioned by way of prohibitions on forms of intergenerational inheritance: No titles of nobility may be passed from parent to child, nor shall the treasonous acts of ancestors result in penalties to children by way of "corruption of blood." "148 Yet Supreme Court Justices have regularly understood that they have the power to speak about families. As we learned in June of 2000 , for example, the Constitution has an affirmative vision of family life. In Troxel $v$. Granville ${ }^{149}$ (popularly styled the "grandparents' visiting rights" case), the Supreme Court held that the State of Washington could not constitutionally confer on judges the ability to order that a range of persons other than legal parents be able to visit children. Not one of the briefs filed in Troxel argued that the United States Constitution did not speak to family life. ${ }^{150}$ Only Justice Scalia's dissent claimed that federal law had no role in correcting what he saw as a misguided provision. ${ }^{151}$ In contrast, his colleagues (through five opinions) all agreed that the Constitution applied, although they disagreed about what flowed from its deployment. ${ }^{152}$

148. U.S. CONST. art. I, $\S 9, \mathrm{cl} .8 ; i d$. art. III, $\S 3, \mathrm{cl} .2$. States are also barred from conferring titles of nobility. Id. art. I, $\$ 10$, cl. 1 ; see Kris Collins, Framers and the Family Revisited (n.d.) (unpublished manuscript, on file with author) (arguing that federal constitutional law at its inception embodied national norms of inheritance).

149. 530 U.S. 57 (2000).

150. Troxel (No. 99-138), 1999 U.S. Briefs LEXIS 138. Sixteen amici briefs were filed; the organizations included the ACLU, the Center for the Original Intent of the Constitution, the Lambda Legal Defense and Education Fund, the AARP, and the National Conference of State Legislatures.

151. Troxel, 530 U.S. at 92 (Scalia, J., dissenting) ("I do not believe that the power which the Constitution confers upon me as a judge entitles me to deny legal effect to laws that (in my view) infringe upon what is (in my view) an unenumerated right.").

152. Exactly what rule emerged from the decision is unclear. Both the plurality opinion by Justice O'Connor and Justice Souter's concurrence stressed the parental right to direct a child's 
Troxel does not stand alone. From the 1920s forward, Justices have articulated federal constitutional norms regarding families, including that legal parents are protected from state intervention absent compelling evidence $^{153}$ and that they have various forms of control over their children such as direction of their education. ${ }^{154}$ Similarly, federal constitutional law has bounded state rules on marriage and sexuality (by banning race-based marriage barriers, by prohibiting polygamy, and by permitting contraception ${ }^{155}$ ) and on child custody, ${ }^{156}$ as well as prohibited discrimination based on whether parents were married at the time of a child's birth. ${ }^{157}$ Given the many cases that address the parental status of men, ${ }^{158}$ the Court could even be understood as specializing in the law of fatherhood.

My claim is not that federal law, statutory or constitutional, specifically regulates all aspects of family life but rather that denominating an issue as about family life has not precluded federal legal regimes from imposing obligations, structuring sanctions, and creating incentives among individuals designated to be family members. Even in areas such as marriage, divorce, alimony, and child custody, which are often listed as comprising the set of "domestic relations" within the aegis of state law, ${ }^{159}$

upbringing without oversight from judges. $I d$. at $65-66$ (plurality opinion); id. at 77-78 (Souter, J., concurring). Justice Thomas's concurrence argued that any legislation limiting parental rights should be subjected to strict scrutiny. Id. at 80 (Thomas, J., concurring). Justice Stevens's dissent, id. at 86 (Stevens, J., dissenting), focused on the child's best interests, whereas Justice Kennedy's dissent argued for judicial authority and restraint, with attention paid to the particulars of individual situations, id. at 100-01 (Kennedy, J., dissenting).

153. See Santosky v. Kramer, 455 U.S. 745,753 (1982) (recognizing the "fundamental liberty interest of natural parents in the care, custody, and management of their child"), cited in Troxel, 530 U.S. at 66 (plurality opinion).

154. See, e.g., Pierce v. Soc'y of Sisters, 268 U.S. 510, 534-35 (1925); Meyer v. Nebraska, 262 U.S. 390, 401 (1923).

155. See Loving v. Virginia, 388 U.S. 1 (1967) (overturning a ban on racial intermarriage, which sixteen states then prohibited and punished); Cleveland v. United States, 329 U.S. 14 (1946) (upholding federal prosecutions based on polygamy); Reynolds v. United States, 98 U.S. 145 (1878) (sustaining a federal conviction for bigamy); Eisenstadt v. Baird, 405 U.S. 438 (1972) (invalidating a ban on the sale of contraception).

156. Palmore v. Sidoti, 466 U.S. 429 (1984) (prohibiting reliance on a parent's interracial marriage as grounds for assigning custody to the other parent).

157. N.J. Welfare Rights Org. v. Cahill, 411 U.S. 619 (1973); Levy v. Louisiana, 39 I U.S. 68 (1968).

158. See, e.g., Michael H. v. Gerald D., 491 U.S. 110 (1989) (holding constitutional a presumption that a man married to a woman is the father of the child); Little v. Streater, 452 U.S. 1 (1981) (requiring state funding for required paternity tests if the alleged father is too poor to pay); Caban v. Mohammed, 441 U.S. 380 (1979) (finding New York law violative of the Equal Protection Clause because unwed mothers but not fathers could withhold consent to adoption); Quilloin v. Walcott, 434 U.S. 246 (1978) (concluding that a state's differential treatment of the rights of divorced biological mothers from biological fathers vis-à-vis adoption of a child did not violate equal protection); Stanley v. Illinois, 405 U.S. 645 (1972) (holding that states must give unwed fathers hearings on their fitness before removing children from their custody).

159. See, e.g., Barbara Ann Atwood, Domestic Relations Cases in Federal Court: Toward a Principled Exercise of Jurisdiction, 35 HASTINGS L.J. 571 (1984); Naomi R. Cahn, Family Law, Federalism, and the Federal Courts, 79 IOWA L. REV. 1073 (1994). 
federal law plays an important role. Indeed, for divorcing couples with certain forms of income, the federal rule on spousal pension rights is central to the division of assets. For couples at lower income brackets, federal welfare laws structure economic options, and, as federal funding diminishes, federal child support obligations become all the more central. ${ }^{160}$ Moreover, international law is playing a growing role in family life as conventions related to children gain adherents and as parents in conflict transport children across national boundaries. ${ }^{16 !}$

Similarly, describing problems as "criminal" - a category also invoked in passing by the majority decision in Morrison and more extensively in the Fourth Circuit's decision ${ }^{162}$ - does not preclude congressional power to legislate. Given that prosecutors rather than victims bring criminal cases, the majority's reference to criminal law in conjunction with the civil rights remedy in VAWA was more of a reach than relating the statute to family law. But embracing rather than contesting the category criminal does not result in a descriptive conclusion that federal law must be silent. Rory Little, John Jeffries, John Gleeson, and Daniel Richman, among others, have detailed the overlap between state and federal law enforcement. ${ }^{163}$ How much crime should be "federalized" is a contemporary subject of debate; ${ }^{164}$ that certain crimes are beyond federal law is a proposition established by Lopez, but that crime as a category is beyond federal jurisdiction is not a statement that any description of the United States's law can support.

In the areas of both family life and crime, state systems currently bear the brunt of dealing with the volume of disputes. But state courts do more of the work for all forms of disputes. Federal filings (of some 300,000 civil and criminal cases annually) are a small fraction of the thirty million disputes brought annually to state courts. ${ }^{165}$ To use (or to fear) quantities of

160. LERMAN \& SORENSEN, supra note 140, at 45.

161. Linda Henry Elrod, Epilogue: Of Families, Federalization, and a Quest for Policy, 33 FAM. L.Q. 843, 851-52 (2000); Merle Weiner, Navigating the Road Between Uniformity and Progress: Driving the Hague Convention on the Civil Aspects of International Child Abduction Forward with Purposive Analyses, 33 COLUM. HUM. RTS. L. REV. (forthcoming 2002).

162. United States v. Morrison, 529 U.S. 598, 612-13, 617 (2000); Brzonkala v. Va. Polytechnic Inst., 169 F.3d 820, 838-42 (4th Cir. 1999) (en banc).

163. A range of federal criminal statutes interact with comparable state provisions; local and federal law enforcement officers often work together, sometimes through cross-deputization. See Rory K. Little, Myths and Principles of Federalization, 46 HASTINGS L.J. 1029, 1061 -70 (1995); John C. Jeffries, Jr. \& John Gleeson, The Federalization of Organized Crime: Advantages of Federal Prosecution, 46 HASTings L.J. 1095 (1995); Daniel C. Richman, The Changing Boundaries Between Federal and Local Law Enforcement, 2 CRIM. JUST. 81 (2000).

164. See TASK Force on the federalization of Criminal Law, aBa CRiminal JustiCE SECTION, THE Federalization OF Criminal LAW (James A. Strazella rptr., 1998); Sara Sun Beale, Federalizing Hate Crimes: Symbolic Politics, Expressive Law, or Tool for Criminal Enforcement?, 80 B.U. L. REv. 1227 (2000).

165. AdMIN. OfFICE OF THE U.S. COURTS, Statistical TABles for the Federal JUDICIARY 25 tbI.C-1 (2000); Nat'l Ctr. for State Courts, Court Statistics Project, Examining the 
work stemming from legal regulation as the basis for reading into the Constitution a prohibition on federal lawmaking gives judges arbitrary and unaccountable power. Calling VAWA a family and criminal law statute does not provide an argument about why Congress could not act. Rather, the interacting legal regimes in these arenas demonstrate the prevalence, in practice, of multi-faceted federalism.

\section{CONCEPTUALIZING THE INJURIES OF VIOLENCE: GLOBAL COUNTERPOINTS AND "LOCAL" ANXIETY}

The layers of lawmaking related to violence, family, crime, and equality go beyond state and federal law within the United States, as the problem of violence against women has become a topic for lawmakers worldwide. Beginning in the late 1940s with the Universal Declaration of Human Rights, ${ }^{166}$ international treaties recognized women's equality. More recent enactments (such as the Convention on the Elimination of All Forms of Discrimination Against Women, ${ }^{167}$ the Declaration on the Elimination of Violence Against Women, ${ }^{168}$ and regional agreements ${ }^{169}$ ) expressly address women's right to physical safety. Indeed, in the Morrison litigation, a group of human rights scholars argued that Congress had the power to enact VAWA as part of its obligation to implement the International Covenant on Civil and Political Rights (which the United States has ratified ${ }^{170}$ ) and to

Work of the State Courts, 1999-2000, at http:/www.ncsc.dni.us/divisions/research/csp/cspstat01 html (last visited Aug. 25, 2001) (reporting more than fifteen million civil, fourteen million criminal, and five million "domestic" filings). The evaluation shifts somewhat if, on the federal side, the many bankruptcy and welfare benefit disputes related to "domestic relations" law are included. For example, about 1.2 million nonbusiness bankruptcy petitions were filed in 2000 , ADMIN. OFFICE OF THE U.S. CoURTS, supra, at 94 tbl.F-2, and the Social Security Administration decided more than 500,000 cases annually, Soc. Sec. Admin., About SSA's Office of Hearings and Appeals, at http://www.ssa.gov/oha/overview.htm (last modifed Mar. 9, 2000).

166. G.A. Res. 217A, U.N. Doc. A/810 (1948); see MARY ANN GLENDON, A WORLd MADE NEW: ElEANOR ROOSEVELT AND THE UNIVERSAL DECLARATION OF HUMAN RIGHTS (2001).

167. Convention on the Elimination of All Forms of Discrimination Against Women, Dec. $18,1979,1249$ U.N.T.S. 13 (entered info force Sept. 3, 1981); see infra notes 186-190, 223-238 and accompanying text.

168. Declaration on the Elimination of Violence Against Women, G.A. Res. 104, U.N. GAOR, 48th Sess., Agenda Item 111, U.N. Doc. A/Res/48/104 (1994).

169. See, e.g., Inter-American Convention on the Prevention, Punishment and Eradication of Violence Against Women, June 9, 1994, art. 5, 33 I.L.M. 1534, 1536 ("Every woman is entitled to the free and full exercise of her civil, political, economic, social and cultural rights ... [and signatories] recognize that violence against women prevents and nullifies the exercise of these rights." ). See generally Claudio Grossman, Domestic Violence in International Law and the InterAmerican System, in U.N. DEP'T OF ECON. \& SOC. AFFAIRS, DIV. FOR THE ADVANCEMENT OF WOMEN, BRINGING INTERNATIONAL HUMAN RIGHTS LAW HOME 50, U.N. Sales No. E.00.IV.3 (2000) (providing an overview of intemational agreements addressing such violence).

170. International Covenant on Civil and Political Rights, adopted Dec. 19, 1966, S. EXEC. DoC. E, 95-2, at 23 (1978), 999 U.N.T.S. 171 (entered into force Mar. 23, 1976). 
enforce customary international law that freed women from violence based on gender bias. ${ }^{171}$

Also beginning in the 1940s, politicians in the United States opposed such transnational lawmaking as a threat to this nation. They relied specifically on states' rights as an argument against participation in the new human rights laws. ${ }^{172}$ Transnational efforts to define equality are therefore relevant in two respects to the contemporary invocation of categorical federalism. First, an overview on gender equality elsewhere makes plain how much at odds the Morrison majority's response is with lawmaking in other countries, acknowledging the links among women's safety, equality, family roles, and economic capacity. Second, the existence of these new definitions of women's rights reveals yet another function of categorical federalism-its role in attempting to buffer the United States from the effects of lawmaking beyond its borders.

\section{A. Developing Human Capabilities and Creating Legal Innovation}

The harms suffered by women have become a subject of study around the world. Illustrative is an international survey, Domestic Violence Against Women and Girls, ${ }^{173}$ issued by UNICEF in June of 2000 . This report concludes that violence against women is "one of the most pervasive of human rights violations, denying women and girls equality, security, dignity, self-worth, and their right to enjoy fundamental freedoms." ${ }^{174}$ While noting that most countries prohibit such violence, the report finds that violations are common and are often

sanctioned under the garb of cultural practices and norms, or through misinterpretation of religious tenets. Moreover, when the violation takes place within the home, as is very often the case, the abuse is effectively condoned by the tacit silence and the passivity displayed by the state and the law-enforcing machinery. ${ }^{175}$

Indeed, although the "family is often equated with sanctuary," the family "is also a place that imperils lives, and breeds some of the most

171. Brief of Amici Curiae on Behalf of the International Law Scholars and Human Rights Experts in Support of Petitioners at 3-15, 22-30, United States v. Morrison, 529 U.S. 598 (2000) (Nos. 99-5, 99-29), 1999 WL 1037253.

172. See LOUIS HENKIN, THE AGE OF RIGHTS $76-77$ (1990) (discussing the United States's "deep isolationism" and fear of importing human rights).

173. UNICEF, DOMESTIC VIOLENCE AGAINST WOMEN AND GIRIS (United Nations Children's Fund Innocenti Research Ctr., Innocenti Digest No. 6, 2000), http://www.uniceficdc.org/publications/pdf/digest6e.pdf.

174. Id. at 2.

175. Id. 
drastic forms of violence perpetrated against women and girls." ${ }^{176}$ In contrast to the jurisdictional lines drawn by the Morrison majority, the UNICEF report refuses to bound its inquiry into the family, culture, and religion. ${ }^{177}$ Rather, the report identifies the systemic and widespread practices of violence against women as predicated upon economic dependency, acculturation to sex roles, and legal and political inequality. Poignantly, "women's increasing economic activity and independence is viewed as a threat which leads to increased male violence," particularly in economies that are themselves in transition. ${ }^{178}$

International analyses also address "human capability," a term used to denote a range of activities including but not limited to economic activity. Since the early 1990s, the United Nations has provided an annual Human Development Report with "balance sheets," listing a rise of women's economic activity in the "progress column" and the high incidence of physical violence against women by their intimate partners on the "deprivation" side. ${ }^{179}$ The variable of gender correlates with education and poverty levels. As Ruth Bader Ginsburg and Deborah Jones Merritt explain, for every one man who is illiterate around the world, two women are, ${ }^{180}$ and seventy percent of the world's poor are women. ${ }^{181}$ Women's risk of violence, their poverty, and their high illiteracy rates relate to women's roles within families. The job of being a parent limits market options, as does the danger of violence. Martha Nussbaum relies on such research for what she terms a feminist argument that attends specifically to women's status as "less well-nourished than men, less healthy, more vulnerable to physical violence and sexual abuse." ${ }^{182}$

176. Id. at 3. While violence against women crosses cultural lines, the grounds and sources of injury reflect cultural pattems. See Lama Abu-Odeh, Comparatively Speaking: The "Honor" of the "East" and the "Passion" of the "West," 1997 UTAH L. REV. 287.

177. See UNICEF, supra note 173, at 1 (commenting, in an opening editorial by Mehr Khan, the Director of the UNICEF Innocenti Research Centre, "Women and children have a right to State protection even within the confines of the family home").

178. Id. at 8 .

179. U.N. Dev. Programme, Human Development Report 1999, at 22, U.N. Sales No. 99.III.B.43 (1999) (“Between 1990 and 1997 women's economic activity rate rose from 34\% to nearly $40 \%$... A quarter to a half of all women have suffered physical abuse by an intimate partner."). Assessments of human security link economic and personal safety. Id. at 36.

180. Ruth Bader Ginsburg \& Deborah Jones Merritt, Affirmative Action: An International Human Rights Dialogue, 21 Cardozo L. REV. 253, 257 (1999); see also U.N. DEV. PROGRAMME, supra note 179, at 132, 138-41, 160-62, 229-41 (providing a "gender-related development index" that includes measures of life expectancy, literary, and income); id. at 140 (reporting that, for example, in India, $39.4 \%$ of women are literate, as contrasted to $66.7 \%$ of men). See generally AMARTYA SEN, DEVELOPMENT AS FREEDOM 191-203, 217-18, 225 (1999) (elaborating the relationship among women's educational levels, fertility rates, and women's economic, social, and political opportunities).

181. Ginsburg \& Merritt, supra note 180, at 257.

182. Martha C. Nussbaum, Women and Human Development: The Capabilities APPROACH 1 (2000). 
The economic and sociological work is both a product and a source of international efforts to obtain recognition of women's equality. ${ }^{183} \mathrm{~A}$ series of constitutional documents recognize women as rightsholders. ${ }^{184}$ Some instruments make more wide-ranging commitments to action for achieving equality than does contemporary equality law in the United States. ${ }^{185}$ For example, in 1979, the United Nations General Assembly promulgated the Convention on the Elimination of All Forms of Discrimination Against Women (CEDAW) ${ }^{186}$ Although signed by then-President Jimmy Carter in 1980 and adopted by more than 165 countries, the United States Senate has not (yet) ratified CEDAW. ${ }^{187}$ That Convention defines prohibited genderbased discrimination to include "any distinction, exclusion or restriction [that] has the effect or purpose of impairing women's and men's equality and exercises of human rights and fundamental freedoms." Further, CEDAW requires that:

State parties shall take in all fields, in particular in the political, social, economic and cultural fields, all appropriate measures, including legislation, to ensure the full development and advancement of women, for the purpose of guaranteeing them the exercise and enjoyment of human rights and fundamental freedoms on a basis of equality with men. ${ }^{188}$

183. See Leila J. RupP, Worlds of Women: The Making of the INTERnational WOMEN's MOVEMENT (1997) (providing a history beginning with the 1878 Congrès international de droit des femmes, the first international women's congress, followed a decade later by a conference called by the U.S. National Woman Suffrage Association, from which the International Council of Women emerged).

184. See Nitza Berkovitch, The Emergence and Transformation of the International Women's Movement, in CONSTRUCTING WORLD CULTURE: INTERNATIONAL NONGOVERNMENTAL ORGanizations SinCE 1875, at 100 (John Boli \& George M. Thomas eds., 1999); Elisabeth Friedman, Women's Human Rights: The Emergence of a Movement, in WOMEN's RIGHTS, HuMAN RIGHTS 18 (Julie Peters \& Andrea Wolper eds., 1995); Annelise Riles, The Virtual Sociality of Rights: The Case of "Women's Rights Are Human Rights," in TranSNATIONAL LEGAL PROCESS: GLOBALISATION AND POWER DISPARITIES (Michael Likosky ed., forthcoming 2001).

185. Ginsburg \& Merritt, supra note 180 , at 273-81.

186. Convention on the Elimination of All Forms of Discrimination Against Women, supra note 167; see Arvonne S. Fraser, The Convention on the Elimination of All Forms of Discrimination Against Women (the Women's Convention), in WOMEN, POLITICS, AND THE UNITED NATIONS 77 (Anne Winslow ed., 1995). "CEDAW," technically the name of the committee empowered with oversight of its deployment, is sometimes used as shorthand as is the term "The Women's Convention." I prefer CEDAW because the term "The Women's Convention" could be read to imply that other conventions, addressing political and civil rights, economic rights, torture, and the like, are not also central to women.

187. See Comms. on Int'1 Human Rights \& Int'l Law, Recommendations on the Ratification of the Convention on the Elimination of All Forms of Discrimination Against Women, 53 REC. ASS'N BAR CITY N.Y. 511 (1998).

188. Convention on the Elimination of All Forms of Discrimination Against Women, supra note 167, art. 3, 1249 U.N.T.S. at 16. Article 5(a) addresses the need "[t]o modify social and cultural patterns of conduct of men and women" to eliminate stereotypes; Article 6 calls on state parties to reduce trafficking in women; Article 7 seeks women's equal participation in formulation 
The "appropriate measures to eliminate discrimination" may include "temporary special measures aimed at accelerating de facto equality between men and women" 189 -in United States parlance "affirmative action." In the early 1990s, the committee superintending the Convention issued a statement that its provisions include prohibitions on violence against women, whether occurring in the family, the community, or other institutions. ${ }^{190}$ A year thereafter, the UN adopted a resolution addressing violence against women. ${ }^{191}$

In addition to such transnational efforts, many countries have created new laws and institutions aimed at undermining gender inequality. Political governance is one arena of concern. Despite women's access to the vote, women remain markedly underrepresented in most democracies. In response, the European Union (EU) supports "parity democracy," by which is meant the "balanced participation" of women and men at all levels of government and in all commissions, committees, and councils of the Community ${ }^{192}$ Concern that only small numbers of women served in elected positions prompted France to enact legislation (the "Electoral loi of 6 June 2000") requiring that equal numbers of women and men candidates, with equal placement on lists of candidates, be put forth for most elections. ${ }^{193}$ Some two dozen countries, including Argentina and South Africa, have variations on this approach. ${ }^{194}$ Governments have also forged new positions, such as the Ministry for Women established in Great

of government policy and for equal employment possibilities; and Article 16 seeks the elimination of discrimination against women in all matters relating to marriage and family relations. $/ d$. arts. $5,6,7,16,1249$ U.N.T.S. at $17,20$.

189. Id. arts. 2(e), 2(f), 4(1), 1249 U.N.T.S. at 16. When equality is achieved, these Articles are to be discontinued. $I$.

190. General Recommendation 19: Violence Against Women, Committee on the Elimination of Discrimination Against Women, 11th Sess., at 5, U.N. Doc. A/47/38 (1992).

191. Declaration on the Elimination of Violence Against Women, supra note 168; Radhika Coomaraswamy \& Lisa M. Kois, Violence Against Women, in 1 WOMEN AND INTERNATIONAL HumaN Rights LAW 177, 182-84 (Kelly D. Askin \& Doreen M. Koenig eds., 1998) (discussing the history and content of the Declaration on the Elimination of Violence Against Women); Elissavet Stamatopoulou, Women's Rights and the United Nations, in WOMEN's RIGHTS, HUMAN RIGHTS, supra note 184, at 36 (providing an overview of the UN mechanisms for advancing women's equal treatment).

192. Mariagrazia Rossilli, Introduction: European Union's Gender Policies, in GENDER POLICIES IN THE EUROPEAN UNION 1, 18 (Mariagrazi Rossilli ed., 2000).

193. Noëlle Lenoir, The Representation of Women in Politics: From Quotas to Parity in Elections, 50 INT'L \& COMP. L.Q. 217, 242-43 (2001); Suzanne Daley, Parity: Thy Name Is Woman, N.Y. TIMES, Feb. 11, 2001, § 4, at 3. See generally SYLVIANE AGACINSKI, PARITY OF THE SEXES (Lisa Walsh trans., Columbia Univ. Press 2001) (1998) (analyzing the political and philosophical complexities of the concept and practice of parity).

194. Eliane Vogel-Polsky, Parity Democracy-Law and Europe, in GENDER POLICIES IN THE EuRoPeAn UnION, supra note 192, at 61; see, e.g., Alice Brown, Deepening Democracy: Women and the Scottish Parliament, in REMAKING THE UNION 103 (Howard Elcock \& Michael Keating eds., 1998); Pippa Norris, Equality Strategies and Political Representation, in SEX EQUALITY POLICY IN WESTERN EUROPE 46 (Frances Gardiner ed., 1997). 
Britain. ${ }^{195}$ That work is part of the effort to implement what both the EU and the United Nations describe as "mainstreaming," 196 bringing questions of women's equality into all policy areas and ensuring that all policies be made with an awareness of their effects on women.

If one axis is political governance and participation, another is the workforce and households. As Norwegian sociologist Arnlaug Leira comments, "Mothers have changed the gender balance in breadwinning. Changing the gender balance in caring may prove even more difficult." 197 In France, the thirty-five-hour work week has become mandatory for much of the workforce, ${ }^{198}$ in part to shift cultural patterns in which women continue to take more responsibility than men for providing care to children, other relatives, spouses, and themselves. ${ }^{199}$ In Denmark, Norway, and Sweden, a portion of all parental leave is reserved to each parent as a "non-transferable right" to prompt both mothers and fathers to take paid time (including, in some instances, part-time) away from their workplaces ${ }^{200}$ Further, in Sweden and Norway, benefits provided upon the

195. See BETTER FOR WOMEN, BETTER FOR ALL: FOURTH REPORT OF THE UNITED KINGDOM OF GREAT BRITAIN AND NORTHERN IRELAND 2 (1999) (providing, as part of the filing required under CEDAW, an overview of the Women's Unit in the cabinet created to ensure that the "whole of Government takes into account women's needs and aspirations").

196. See Making Women COUNT: INTEgRating GENDER InTo LaW AND POlicy-Making (Fiona Beveridge, Sue Nott \& Kylie Stephen eds., 2000) (analyzing efforts at integrating gender into policymaking in five EU countries). See generally Catherine Barnard, Gender Equality in the EU: A Balance Sheet, in THE EU AND Human RIGHTS 215, 220-21 (Philip Alston ed., 1999) (providing an overview of case law and legislation); Christopher McCrudden, Mainstreaming Equality in the Governance of Northern Ireland, 22 FORDHAM INT'L L.J. 1696, 1699-1701 (1999) (examining efforts at enhancing equality).

197. Arnlaug Leira, Caring as Social Right: Cash for Child Care and Daddy Leave, 5 SoC. POL. 362, 375 (1998). See generally PARENTAL LEAVE at x-xi (Peter Moss \& Fred Deven eds., 1999) (stating that, despite efforts to achieve gender neutrality, "women remain the overwhelmingly dominant group among those taking leaves").

198. French Parliament Approves 35-Hour Working Week, AGENCE FRANCE PRESSE, Dec. 16, 1999, LEXIS, Nexis Library, Agence France Presse File (stating that the law applies to all companies with more than twenty employees and, as of 2002, to all companies); see also Jeanne Fagnani, Parental Leave in France, in PARENTAL LEAVE, supra note 197, at 69 (discussing how leave policies may reinforce gender discrimination in labor markets).

199. See Deborah M. Figart \& Ellen Mutari, Degendering Work Time in Comparative Perspective: Alternative Policy Frameworks, 56 REv. SOC. ECON. 460, 462 (1998) (describing Swedish feminists as among the first to propose "reductions in paid working time as a means of redistributing domestic labor"). In the United States, women disproportionately bear the burden of household work. See ARLIE HochsChILD, The SECOND SHIFT: WORKING PARENTS AND THE REVOLUTION AT HOME (1989).

200. Payment structures in countries vary, with some having "flat-rate allowances" and "parental wages," and others replacing earnings at the same levels as unemployment or illness. In terms of "take-up rates" (i.e. usage), the variables include the amount of economic benefit provided, the existence of child-care providers, and the level of professionalism of women workers. In Sweden, 450 days are paid from birth until a child is eight; 360 are paid at full salary, and 180 extra days are provided per additional child. See Suzan Lewis, Janel Smithson \& Julia Brannen, Young Europeans' Orientations to Families and Work, 562 ANNALS AM. ACAD. POL. \& SOC. SCI. 83, 85 (1999); MINISTRY OF CHILDREN \& FAMILY AFFAIRS, THE RIGHTS OF PARENTS OF SMALl ChILDREN IN NORWAY (2000); see also Françoise Core \& Vassiliki Koutsogeorgopoulou, Parental Leave: What and Where?, OECD OBSERVER, Aug. 1995, at 15 
birth of a child are reduced if both spouses do not participate by taking time off from work. ${ }^{201}$ As Leira explains, "In the Nordic countries parental leave is one element in more comprehensive legislation to promote gender equality." 202 Such provisions point to an appreciation that "[i]ncreasingly,... what differentiates gender roles is not whether individuals have a job, but the amount of time spent in paid employment." 203

A third focus is on women's lack of physical security. Although VAWA's attempt to make certain assaults a breach of national norms did not succeed in the United States, that approach is being adopted internationally, as rape is comprehended-for the first time-to be a crime against humanity, a war crime. ${ }^{204}$ In the winter of 2001, an international tribunal dealing with war crimes in the former territories of Yugoslavia convicted perpetrators of such crimes. ${ }^{205}$ This premise has also been codified in the Treaty of Rome, ${ }^{206}$ "the first international treaty to recognize

(describing Belgium's "career breaks," available for up to five years and for needs unrelated to children, and noting that the three-month leave associated with the United States is too short to qualify as parental leave by some countries' standards).

201. In Norway, participation rates by fathers rose rapidly when the "use it or lose it" provisions came into play. See Amlaug Leira, Cash-for-Child Care and Daddy Leave, in PARENTAL LEAVE, supra note 197, at 267, 275 (describing how, since the introduction of the "daddy quotas," about seventy percent of eligible fathers in Norway have taken the leave); see also U.N. DEv. PROGRAMME, supra note 179, at 82 ("Fathers must use at least 4 weeks of the parental leave" time of forty-two weeks at full pay or fifty-two weeks at eighty percent pay or that period is lost.).

202. E-mail from Amlaug Leira, Professor of Sociology, University of Oslo, to author (Feb. 9, 2001) (on file with author). Whether this strategy is successful is unclear. As Leira comments, one small study of the use of "father's leave" indicated that while, in some families, it facilitated a woman's return to the workforce, in others, fathers spent time at home but functioned as "mothers' helpers." Leira, supra note 197, at 373-74.

203. Figart \& Mutari, supra note 199, at 465 (discussing whether part-time employment reinforces occupational segregation by gender and the debate among feminists about whether the shorter work week promotes women's equality).

204. See Rhonda Copelon, Gendered War Crimes: Reconceptualizing Rape in Time of War, in WOMEN's RIGHTS, HUMAN RIGHTS, supra note 184, at 197, 200-01 (explaining that, while rape has been long prohibited, it was conceptualized as a dignitary rather than a violent injury and was not listed under the Geneva Convention as one of the "grave breaches," a predicate to universal jurisdiction); Dorean M. Koenig \& Kelly D. Askin, International Criminal Law and the International Criminal Coun Statute: Crimes Against Women, in 2 WOMEN AND INTERNATONAL HUMAN Rights LAW, supra note 191, at 3 (2000); Catharine A. MacKinnon, Rape, Genocide, and Women's Human Rights, in MASS RAPE: THE WAR AGAINST WOMEN IN BOSNIAHERZEGovina 183 (Alexandra Stiglmayer ed., 1994); Theodor Meron, Rape as a Crime Under International Humanitarian Law, 87 AM. J. INT'L L. 424 (1993).

205. See Prosecutor v. Kunarac, Case Nos. IT-96-23-T, IT-96-23/1-T (Int'l Crim. Trib. for Former Yugoslavia Feb. 22, 2001), http://www.un.org/icty/ind-e.htm; Marlise Simons, Bosnian War Trial Focuses on Sex Crimes, N.Y. TIMES, Feb. 18, 2001, at A4. For structural overviews of legal efforts to redress gender-based violence in war, see generally Judith Gardam \& Michelle Jarvis, Women and Armed Conflict: The International Response to the Beijing Plafform for Action, 32 Colum. HuM. RTS. L. Rev. 1 (2000); and Patricia M. Wald, Judging War Crimes, 1 CHI. J. INT'L L. 189 (2000).

206. Rome Statute of the International Criminal Court, July 17, 1998, U.N. Doc. A/CONF.183/9, http://untreaty.un.org/English/notpubl/rome-en-c.htm. As of November 1, 2001, 
a range of acts of sexual and gender violence as among the most serious crimes under international law," ${ }^{207}$ to be redressed in the International Criminal Court.

This brief sketch highlights the degree to which male prerogatives to run or to dominate governments, workplaces, households, international relations, and war are being challenged through both texts and practices. Globalism has helped to make plain the patterns of inequality. Technology has enabled individuals, nongovernmental organizations (NGOs), and countries committed to diminishing such inequality to communicate with each other. As a result, transnational understandings are developing that reflect the degree of transformation needed for women to achieve equality. Reorganization of all aspects of daily life, from homes to streets, markets, and politics is required. ${ }^{208}$ Many of these remedial efforts are not continuous with the political cultures in which they are placed but are disjunctive interruptions of prior patterns. Illustrative is the change to democratic parity in France; the "citizen" unmodified had been the tradition in French law

139 nations had signed and 43 had ratified the Treaty. Coalition for an Int'l Criminal Court, The CICC International Criminal Court Home Page, http://www.igc.org/icc/ (last visited Nov. 1, 2001). The United States became a signatory at the end of President Clinton's term, but many within the Senate have opposed ratification. See, e.g., 147 CONG. REC. E13 (daily ed. Jan. 3, 2001) (reprinting an article, No to a World Court, submitted by Rep. Doug Bereuter of Nebraska). The Bush Administration has announced its opposition. Steven Mufson \& Alan Sipress, U.N. Funds in Crossfire over Court; Exemption Sought for U.S. Troops, WASH. POST, Aug. 16, 2001, at $\mathrm{A}$.

207. Cate Steains, Gender Issues, in The InTERnational Criminal CourT: The MAKING OF THE ROME STATUTE 357, 357 (Roy S. Lee ed., 1999) (footnote omitted). Women are written into the law of the court in three respects: as victims, as witnesses in need of specific services and rules, and as judges and prosecutors. In terms of women as victims, see Rome Statute of the International Criminal Court, supra note 206, arts. 8(2)(b)(xxii), 8(2)(e)(vi), 7(1)(g), 2(f), which defines war crimes and crimes against humanity to include "[c]ommitting rape, sexual slavery, enforced prostitution, [and] forced pregnancy." Specific reference is made to trafficking in "women and children." Id. art. 7(2)(c). Targeted persecutions are defined to include those based on "political, racial, national, ethnic, cultural, religious, and gender" grounds. $l d$. art. 7(1)(h). In terms of women as witnesses, see id. art. 54(1)(b), which provides that prosecution staff must "respect the interests and personal circumstances of victims and witnesses," including age and gender; and id. art. 68, which states that the court must "protect the safety, physical and psychological well-being, dignity and privacy of victims and witnesses." In terms of women as judges and prosecutors, see $i d$. art. 36(8)(a)(iii), which calls for state parties to take into account the need for "fair representation of female and male judges"; id. art. 36(8)(b), which requires that state selection processes "take into account the need to include judges with legal expertise on ... violence against women or children"; and id. art. 42(9), which requires the Prosecutor to have advisors with legal expertise in "gender violence and violence against children."

208. See STEERING COMM. FOR EQUALITY BETWEEN WOMEN \& MEN, COUNCIL OF EUR., THE STRATEGIES, ROLE, \& FUNCTIONS OF NGOS WORKING FOR THE PROMOTION OF EQUALITY Between Women and Men, Proceedngs (1996); Shelly Inglis, Re/Constructing Right(s): The Dayton Peace Agreement, International Civil Society Development, and Gender in Postwar Bosnia-Herzegovina, 30 Colum. HUM. RTs. L. REv. 65, 97-105 (1998); Afra Afsharipour, Note, Empowering Ourselves: The Role of Women's NGOS in the Enforcement of the Women's Convention, 99 COLUM. L. REv. 129 (1999). 
until the recent enactments aimed at achieving parity for women and men. ${ }^{209}$

One cannot therefore dismiss cross-cultural comparisons as evidence that some innovation, "natural to them," cannot provide insight "here." Categories such as the family or war, previously used to preclude gender equality norms from operating, are no longer understood as prior to and thereby exempt from new rules and practices. Returning to the United States, Morrison becomes remarkable not just as a "local" example of a Supreme Court override but as parochial refusal to permit innovations aimed at altering gender roles in the face of a national and growing worldwide consensus that all social institutions require reconsideration in light of knowledge of gender subordination.

\section{B. Fears of "the Foreign" Within}

These developments abroad illuminate another aspect of the appeal of categorical federalism in the United States. Insistence on the "truly local" as a jurisdictional limit underscores territorial boundaries in an effort to defend against waves of transnational laws and increasingly homogenized cultures. Categorical federalism therefore promises (or threatens, depending on one's view) not only to limit (or undo) the New Deal, but also to reinscribe isolationist foreign affairs policies aimed at returning the globe to a description of the planet rather than a powerful presence within the physical boundaries of the United States. Categorical federalism deploys "the local" as if it is inevitably a site of participatory democracy that protects some categories of human enterprise from distant power by safely ensconcing them in decisional processes controlled by one's friends, one's neighbors, and oneself.

Categorical federalism is thus specially responsive to the history of this nation's birth in rebellion from a distant and centralized power. The central gesture of the American Revolution-separation from King George-is reenacted by claiming that " $t]$ he Constitution requires a distinction between what is truly national and what is truly local," 210 thereby limiting Washington's power. Moreover, a tenet of constitutional faith, that the Constitution defines and confines all power, is invoked to justify the Court's exercise of its own power. In addition, categorical federalism has psychological appeal; "people often believe that there is an underlying

209. Proponents of the shift debate the degree to which it alters French law. See, e.g., Lenoir, supra note 193, at 245, 247 (discussing those who see parity as making a fundamental change and arguing that parity does not alter the universalism of citizenship but is a "tool," an "operational mechanism ... to ensure ... equal access to political responsibility," yet also noting that it is "a sign [that France] is more open to the pluralism that it must itself incorporate").

210. United States v. Morrison, 529 U.S. 598, 617-18 (2000). 
essence or reason for categories to be the way that they are." ${ }^{211}$ Categorical federalism thus helps to cushion anxiety occasioned by dissolving boundaries.

Working in conjunction with other precepts of current federalism jurisprudence about the relationship between "the local" and "the international," the boxes constructed through categorical federalism become fortresses designed to ward off incursions not only from the national government but also from abroad. ${ }^{212}$ This posture also has a history. The claim that states' rights ought to preclude the application of international human rights law was raised in the early 1950s, when, after the creation of the United Nations and the promulgation of the Universal Declaration of Human Rights, Senator John Bricker proposed a constitutional amendment that would have limited federal treaty power if deployed to undercut states' rights. ${ }^{213}$ According to one commentator, "Bricker wanted to insure that international agreements would not lead to United Nations interference or more liberal social and economic policies and legislation in the United States." 214

Although the Bricker Amendment did not become law, some believe it has become fact - through practices of the Senate that consistently limit the application of international laws by reference to federalism. ${ }^{215}$ For example, when the Clinton Administration proposed that the Senate ratify CEDAW,

211. Spalding \& Murphy, supra note 5, at 864 (discussing experiments attempting to locate the role that background knowledge plays in influencing category representation).

212. See, e.g., John C. Yoo, Globalism and the Constitution: Treaties, Non-Self Execution, and the Original Understanding, 99 COLUM. L. REV. 1955 (1999) (arguing against participation in a range of transnational agreements and against federal courts' application of those laws as part of international customary law). But see Peter J. Spiro, The New Sovereigntists: American Exceptionalism and Its False Prophets, FOREIGN AFF., Nov.-Dec. 2000, at 9 (criticizing such views).

213. S.J. Res. 130, 82d Cong., 98 CONG. REC. 908 (1952) ("No treaty or executive agreement shall be made respecting the rights of citizens of the United States protected by this Constitution..."), reprinted in DUANE TANANBAUM, THE BRICKER AMENDMENT CONTROVERSY 222 (1988). An alternative version read: "A provision of a treaty which conflicts with this Constitution shall not be of any force and effect. ... A treaty shall become effective as internal law in the United States only through legislation which would be valid in the absence of treaty." TANANBAUM, supra, at 91.

214. Id. at 31. Bricker had support from leaders of the American Bar Association, $i d$. at 2-31, and from a "coalition of Republicans and conservative, mostly southern, Democrats" who had worked together against other legislative proposals, id. at 43. Proponents also included some businessmen, who created the Foundation for Study of Treaty Law, some doctors opposed to "socialized medicine," and Vigilant Women for the Bricker Amendment, fearful of the UN and International Labour Organization's effects on the United States. Id. at 115-18. However, disagreements about exact texts ensued, and President Eisenhower viewed the amendment as unduly restrictive. $I d$. at 79 .

215. See Louis Henkin, U.S. Ratification of Human Rights Conventions: The Ghost of Senator Bricker, 89 AM. J. INT'L L. 341 (1995); see also TANANBAUM, supra note 213, at 199203 (detailing how the Eisenhower Administration undermined support through practical avoidance); Lori Fisler Damrosch, The Role of the United States Senate Concerning "SelfExecuting" and "Non-Self-Executing" Treaties, 67 CHI.-KENT L. REV. 515 (1991) (examining the general question of treaties' domestic application). 
the executive also submitted "reservations, understandings, and declarations" (RUDs)-caveats used in international treaty-making to enable selective adherence to treaty provisions. ${ }^{216}$ The CEDAW RUDs specified that the Convention's provisions would not be enforceable domestically; that ratification would not result in "changing U.S. law in any respect." ${ }^{217}$ Further, in what is termed a "federalism understanding," the RUDs specify that the allocation of power between state and national governments would be unaffected. ${ }^{218}$ Parallel reservations accompanied the United States's joining of the International Convention on the Elimination of All Forms of Racial Discrimination, ${ }^{219}$ and of the International Covenant on Civil and Political Rights. ${ }^{220}$ Federalism concerns have also been proffered as the rationale for the United States's refusal to ratify the Convention on the Rights of the Child. ${ }^{221}$

216. Malvina Halberstam, United States Ratification of the Convention on the Elimination of All Forms of Discrimination Against Women, 31 GEO. WASH. J. INT'L L. \& ECON. 49, 55 (1997).

217. Convention on the Elimination of All Forms of Discrimination Against Women: Hearing Before the S. Comm. on Foreign Relations, 103d Cong. 13 (1994) (statement of Jamison S. Borek, Deputy Legal Advisor, Department of State) [hereinafter CEDAW Hearings]. In contrast, in 1909, when the Mann Act was pending, the participation by the United States in an "international agreement for the suppression of the white slave traffic" was proffered as a reason to change federal law by enacting those criminal provisions. See WHITE SLAVE TRAFFIC, H.R. REP. No. 6l47 , at 3 (1909).

218. See S. EXEC. REP. No. 103-38 (1994). The report states that:

[T] he United States understands that the Convention shall be implemented by the Federal Government to the extent that it exercises jurisdiction over the matters covered therein, and otherwise by the State and local governments. To the extent that state and local governments exercise jurisdiction over such matters, the Federal Government shall, as necessary take appropriate measures to ensure the fulfillment of this Convention.

Id. at 51. Discussion at the hearings indicated that, while the Convention could not be a vehicle for federal legislation, joining the Convention meant conformance not only in arenas currently subject to federal law. See CEDAW Hearings, supra note 217, at 11 (statement of Jamison S. Borek, Deputy Legal Advisor, Department of State); Ann Elizabeth Mayer, Reflections on the Proposed United States Reservations to CEDAW: Should the Constitution Be an Obstacle to Human Rights?, 23 HASTINGS CONST. L.Q. 727 (1996). The Convention requires party states, when filing reports, to discuss the status of such reservations. See Guidelines for Preparation of Reports by States Parties, Committee on the Elimination of Discrimination Against Women, 16th Sess., U.N. Doc. CEDAW/C 7/Rev.3 (1996); U.N. DEP'T OF ECON. \& SOC. AFFAIRS, ASSESSING THE STATUS OF WOMEN: A GUIDE TO REPORTING UNDER THE CONVENTION ON THE ELIMINATION OF ALL FORMS OF DISCRIMINATION AGAINST WOMEN (2000) [hereinafter ASSESSING THE STATUS OF WOMEN].

219. Convention on the Elimination of All Forms of Racial Discrimination, opened for signature Mar. 7, 1966, S. EXEC. DoC. C, 95-2 (1978), 660 U.N.T.S. 195. The United States ratified this convention in 1994. 140 CONG. REC. S7634 (daily ed. June 24, 1994) (listing caveats); see also S. EXEC. REP. No. 103-29, at 24 (1994) (noting that the treaty does not "federalize the entire range of anti-discrimination actions").

220. See 138 CONG. REC. 8071 (1992) ("[T]o the extent that state and local govemments exercise jurisdiction over such matters, the Federal Government shall take measures appropriate to the Federal system to the end that the competent authorities of the state or local governments may take appropriate measures for the fulfillment of the Covenant.").

221. Peter J. Spiro, The States and International Human Rights, 66 FordHAM L. REV. 567, 574-75 (1997). 
States' rights are one set of prerogatives to be protected; gender roles are another. Since the 1940s, the fear of international law undoing gendered relationships in the United States has been express. The theme emerged in hearings on the Bricker Amendment, ${ }^{222}$ and has now been put forth vividly through a 2001 Heritage Foundation publication entitled How U.N. Conventions on Women's and Children's Rights Undermine Family, Religion, and Sovereignty. ${ }^{223}$ That monograph argues that the implementation of CEDAW undervalues the nuclear family and marriage by encouraging mothers to "leav[e] their children in the care of strangers and enter[] the workforce." ${ }^{224}$ Complaining that the "United Nations has become the tool of a powerful feminist-socialist alliance that has worked deliberately to promote a radical restructuring of society," the monograph calls on Congress to devote time and resources to protect against the dangers the UN poses to sovereignty. ${ }^{225}$

These concerns about the influence of "foreign" ideas are based on accurate appraisals of the capacity for ideas and practices to transcend boundaries. But an assumption that bolstering states' and nations' sovereignty could achieve safety from such influences is ill-founded. The relationships among the local, the national, and the international are yet more complex. Within the United States, localities are turning to international law as a model for their own lawmaking. For example, although the United States Senate has yet to ratify CEDAW, the City of San Francisco has, making it a part of its local law in $1998 .{ }^{226}$ (Since then, the city's Departments of Juvenile Services and of Public Works have filed reports, as CEDAW requires on an international level, detailing the results of "gender analyses" to understand the role of gender in their processes, structures, and decisions.) ${ }^{227}$ And, as of 2000 , nine states, the Territory of Guam, sixteen counties, and thirty-eight cities have enacted ordinances calling on the United States to ratify CEDAW. ${ }^{228}$

222. See TANANBAUM, supra note 213 , at 85 (citing testimony from a member of the Chamber of Commerce opposed to the International Labour Organization's proposals for provisions for mothers: "Had the founding fathers of the United States been thinking of compacts regarding layettes and mothers' milk when they had written that treaties would be a part of the supreme law of the land?"); see also supra note 214 (discussing the Vigilant Women for the Bricker Amendment).

223. Patrick F. Fagan, How U.N. Conventions on Women's and Childoren's Rights UNDERMINE FAMILY, RELIGION, AND SOVEREIGNTY (Heritage Found., The Heritage Foundation Backgrounder No. 1407, 2001), http:/www.heritage.org/library/backgrounder/bg1407.html.

224. Id. at 2.

225. Id. at 21 .

226. S.F., CAL., ADMIN. CoDE ch. 12K.1 (2001), http://www.amlegal.com/sanfran/.

227. See S.F. COMM'N ON THE STATUS OF WOMEN AND CEDAW TASK FORCE, A GENDER ANALYSIS: IMPLEMENTING THE CONVENTION ON THE ELIMINATION OF ALL FORMS OF DisCRIMINATION AGAINST WOMEN (1999); S.F. CEDAW TASK FORCE, FOURTH PROGRESS REPORT (2001), http:/www.ci.sf.ca.us/cosw/cedaw/cedaw_5.htm.

228. Women's Inst. for Leadership Dev. for Human Rights, CEDAW Around the U.S., at http://www.wildforhumanrights.org/cedaw_around_us.html (last visited Nov. 1, 2001) (reporting 
The legality of local lawmakers engaging with international human rights was also the subject of decisionmaking in 2000 by the United States Supreme Court. In Crosby v. National Foreign Trade Council, ${ }^{229}$ the Court imposed some limits by relying on the category of "the international" to preclude certain forms of local innovation. In Crosby, commercial litigants challenged a Massachusetts boycott on goods from Burma. In defense of its policy, Massachusetts argued that its police powers supported its refusal to spend state dollars on goods produced in violation of its local standards. ${ }^{230}$ The Supreme Court held, however, that Massachusetts could not refuse Burmese goods, because federal statutory provisions and executive actions addressed the issue, preempting the state's rules. ${ }^{231}$ The Burma boycott case is thus an example of "the local" (Massachusetts) voluntarily allying itself with "the international" (human rights law) and defining local obligations in reference to international standards. Readers of that decision disagree about the breadth of its import, with some claiming it illustrative of a conventional preemption analysis and others understanding it to restate the exclusivity principle that foreign affairs policy be made with "one voice," speaking from Washington. ${ }^{232}$ However read, the local is constrained if not prohibited when it seeks to play globally. ${ }^{233}$

on activity as of August 2000). The texts of these resolutions vary; some seek national ratification while others also require local implementation. In addition, the Working Group on the Ratification of CEDAW, co-chaired by the National Spiritual Assembly of the Bahai's of the United States and the National Federation of Women's Clubs, is promoting national adoption of CEDAW. See Tracey Parr, CEDAW at a "Local" Level 2-5 (Apr. 5, 2001) (unpublished memorandum, on file with author).

229. 530 U.S. $363(2000)$.

230. Brief for Petitioner at 19-20, Crosby (No. 99-474), 2000 WL 35850.

231. Crosby, 530 U.S. at 380-81. Justice Souter filed the majority opinion. Justice Scalia, writing on behalf of himself and Justice Thomas, concurred to protest the majority's mode of interpretation through reliance on materials outside the statute's text. Id. at 388-91 (Scalia, J., concurring).

232. Crosby has already proved to be a wellspring of scholarly debate. See, e.g., Jack Goldsmith, Statutory Foreign Affairs Preemption, 2000 SUP. CT. REV. 175, 177-78, 216-22 (reading Crosby as exemplary of a minimalist approach to statutory foreign affairs preemption); Edward T. Swaine, Crosby as Foreign Relations Law, 41 VA. J. INT'L L. 481, 483, 494-501 (2001) (arguing that Crosby illustrates the Court's appreciation for the importance of executive authority in foreign affairs). Both Mark Tushnet and Ernest Young read Crosby as evidencing a presumption in favor of preemption in foreign affairs. See Mark Tushnet, Globalization and Federalism in a Post-Printz World, 36 TULSA L.J. 11, 22 (2000); Ernest A. Young, Dual Federalism, Concurrent Jurisdiction, and the Foreign Affairs Exception, 69 GEO. WASH. L. REV. 139,179 (2001). Young argues that such a presumption is unworkable in today's world of overlapping boundaries, as was the earlier effort, described as "dual federalism," which was aimed decades ago at making sharp delineations between state and federal powers. Id. at 177-78. Other discussion about the desirability of federal control to enable "one voice" in foreign policy can be found in Lea Brilmayer, Federalism. State Authority, and the Preemptive Power of International Law, 1994 SUP. CT. REV. 295; and Peter J. Spiro, Foreign Relations Federalism, 70 U. COLO. L. REV. 1223 (1999).

233. See Org. for Int'l Inv., State and Municipal Sanctions Survey (Apr. 27, 2001) (unpublished memorandum, on file with author) (reporting on a survey to learn of the effects of Crosby and determining that a majority of responding localities had halted enforcement or rescinded regulations as a consequence). 
But many of today's economic interactions do not track national boundaries, a point powerfully illustrated by Crosby and well-known in practice to consumers able to find the same commodities around the world. Technology not only renders the local visually indistinct (as retailers, products, and peoples reappear from site to site), but also enables nonlocal participants to play major roles in "local" political practices. Massachusetts's paper goods may come from Burma; its foodstuffs from other places, its inhabitants from hundreds of countries, and the funds for its political campaigns from people within and without the United States. ${ }^{234}$

Further, Massachusetts did not itself conceive of the idea of boycotting goods made through forced labor. Its human rights ordinance was achieved through a mixture of local, national, and transnational organizing efforts, which Harold Koh terms "issue networks." ${ }^{235}$ Such practices are not new. Voluntary associations are often organized in layers (national, state, and local) to link activists in this country and abroad. In the early part of the twentieth century, for example, women's clubs in the United States coordinated to help create "mothers' pensions." 236 More recently, a wave of local ordinances objected to apartheid in South Africa, ${ }^{237}$ as others have sought to ban land mines ${ }^{238}$ and to enhance women's rights. This list does not cover the spectrum of local ordinances, which range from expressive efforts to seek social and political change at a national level (such as cities calling for the ratification of CEDAW) to reliance on a locality's economic or political power to produce immediate changes in practices abroad (such as the provision at stake in Crosby) to the use of international exchange to enhance a municipality's economy.

234. Cf. Gregory v. Ashcroft, 501 U.S. 452, 458 (1991) (discussing the benefits of local governance). The classic argument is that a smaller unit permits more participation and enhances the ability of individuals to have impact, a proposition in need of revisiting given the role of extralocal organizations in making local policy. See Spiro, supra note 221, at 585-87 (discussing the role Mexican commercial interests played after California enacted an anti-immigrant proposition).

235. Koh, Bringing International Law Home, supra note 9, at 649; see also BRIAN HoCKING, LOCALIZING FOREIGN POLICY: NON-CENTRAL GOVERNMENTS AND MULTLAYERED DIPLOMACY (1993) (analyzing such activities in Australia, Canada, and the United States and describing the development as "multilayered diplomacy").

236. SKOCPOL, supra note 103 , at $464-65$ (detailing "deliberate, organized, state-by-state efforts of associations of (mostly) married women" such as the National Congress of Mothers and the General Federation of Women's Clubs).

237. See JANice Love, ThE U.S. ANTI-APARTHEId MOVEMENT: LOCAL ACTIVISM IN Global POlITICS (1985); Peter J. Spiro, Note, State and Local Anti-South Africa Action as an Intrusion upon the Federal Power in Foreign Affairs, 72 VA. L. REV. 813 (1986). In the nineteenth century, localities also coordinated to lobby for shifts in national policy. See Kathryn Kish Sklar, "Women Who Speak for an Entire Nation": American and British Women in the World Anti-Slavery Convention, London, 1840, in THE ABOLITIONIST SISTERHOOD: WOMEN'S POlitical Culture in ANTEBellum America 301 (Jean Fagan Yellin \& John C. Van Home eds., 1994); Joshua Civin, Civic Experiments: Community-Building in Baltimore and Liverpool, 1785-1835 (unpublished D. Phil. dissertation, Oxford University, draft 2001) (on file with author).

238. Koh, Bringing International Law Home, supra note 9, at 655-63 (detailing the process by which "norm entrepreneurs" met, formed coalitions, and campaigned against land mines). 
These enactments might be read as demonstrating the genius of rigorous enforcement of federalism boundaries, enabling experimentation generated by varying legal regimes. But such an interpretation misses the political purposes that are the predicates of localities' involvement with labor standards and with CEDAW. Proponents' goals are to change local, national, and international laws; their means deploy local actors working in concert with outsiders. To conceive of local action as rooted in specific conditions and indigenous to a particular place is to miss how often that work is a product of broad efforts to shift social policy. New technologies facilitate national and international campaigns by repeat-players, who organize campaigns for issues from those as seemingly parochial as elections of local judges ${ }^{239}$ to those evidently transnational, sometimes in an effort to generate universal human rights and other times horrifyingly to destroy them. In short, not only does categorical federalism fail as a description; it is unattainable as an aspiration. In contrast, multi-faceted federalism provides the better account of the layers of political authority now inevitably and sometimes uncomfortably present.

\section{CONCLUSION: THE INVENTIONS AND RISKS of Multi-Faceted Federalism}

An absence of bounded categories may be unsettling but, in lieu of (false) comfort, multi-faceted federalism offers something else, hopefully more useful if less supportive. Under the rubric of multi-faceted federalism, the deployment of categories is accompanied by a sense that they are neither exclusive nor necessarily enduring. With an understanding that "the local" and "the national" are not naturally bounded sites, multi-faceted federalism serves as a reminder about how much work is required to make democratic institutions accountable, at any level. The diminished clarity of physical boundaries becomes an invitation to renew interest in the work of local, subnational, and transnational structures, to interrogate current practices, and to imagine new ones. Freed from a sense of siege and a desire for fortifications, inquiry can proceed about the vitality of the United States's institutions and the array of joint ventures that subnational organizations have created.

How could federalism discussions change? First, United States history ought to be retold to recognize the impressive contributions of local political structures. Rather than reading this century as a triumph of the

239. See William G. Kelly, Selection of Judges, ABA JUD. DIV. REC., Winter 2000, at 3 (discussing the role of the Chamber of Commerce in elections of judges in different states); Anthony Champagne, Interest Groups and Judicial Elections 8 (2000) (unpublished paper prepared for the Summit on Improving Judicial Selection, on file with author) (also discussing efforts to influence state judicial elections). 
national on the one hand or as a narrow escape from federal overreaching on the other, ${ }^{240}$ the persistence of local governance structures should be highlighted. Take the example of Indian tribes, which, in the face of federal efforts expressly aimed at "termination" of tribal identity, have had force sufficient to require return of tribal artifacts and the fulfillment of treaty obligations. ${ }^{241}$ Consider also the powerful role of states and cities, which, as demonstrated by the election of 2000 , remain central players in national elections. Not only have local forms proven to be notably resistant to collapse through nationalization, they have also generated a range of national but not federal institutions. Indeed, as Theda Skocpol comments, the layers of federalism with its multiple sites of power create an "opportunity structure" that has made the United States specially nurturant to an array of associations. ${ }^{242}$

Thus, and second, we ought to pay more attention to the legal and political import of the many forms of federalism extant within this country. One important example is the interstate compact, which permits lawful means for joint ventures between contracting states. ${ }^{243}$ A classical use of compacts has been to resolve border disputes. But dozens of compacts now do more, ranging from sharing natural resources ${ }^{244}$ to managing transportation systems ${ }^{245}$ to administering economic programs. ${ }^{246}$ The use of

240. Compare Edward L. Rubin \& Malcolm Feeley, Federalism: Some Notes on a National Neurosis, 41 UCLA L. REV. 903 (1994) (arguing that federalism's proponents cannot demonstrate its utility and that the only purpose served by states is decentralization), with Daniel B. Rodriguez, State Constitutionalism and the Domain of Normative Theory, 37 SAN DIEGo L. REv. 523 (2000) (addressing the vitality of state institutions and analyzing the function and role of state constitutionalism).

241. See, e.g., Native American Graves Protection and Repatriation Act, 25 U.S.C. $\S \S 3001-$ 3013 (1994) (requiring inventorying of tribal materials and their return). In the $1870 \mathrm{~s}$, federal policies allotted land to individual members of tribes in an explicit effort to diminish tribal identity. Resnik, supra note 102 , at 703 . In the 1950 s, the federal government again enacted policies diminishing tribal identity. Id. at 727-28.

242. Theda Skocpol, The Tocqueville Problem: Civic Engagement in American Democracy, 21 SOC. SCI. HIST. 455,472 (1997).

243. VINCENT V. THURSBY, INTERSTATE COOPERATION: A STUDY OF THE INTERSTATE COMPACT (1953); FREDERICK L. ZIMMERMANN \& MITCHELl WENDELL, THE INTERSTATE COMPACT SINCE 1925 (1951); Kevin J. Heron, The Interstate Compact in Transition: From Cooperative State Action to Congressionally Coerced Agreements, 60 ST. JOHN'S L. REV. 1, 8-9 (1985). Well over a hundred formal compacts (involving anywhere from two to fifty states, as well as the District of Columbia and Puerto Rico) exist. See CoUnCIL OF STATE Gov'TS, INTERSTATE COMPACTS \& AGENCIES (1995).

244. E.g., Bear River Compact, Pub. L. No. 85-348, 72 Stat. 38 (1958); IDAHO CODE § 423402 (Michie 1990); UTAH CODE ANN. \$ 73-16 (Supp. 2001); WYO. STAT. ANN. § 41-12-101 to -102 (Michie 2001) (allocating water rights among Idaho, Utah, and Wyoming); see Jeffrey Uhlman Beaverstock, Learning To Get Along: Alabama, Georgia, Florida and the Chattahoochee River Compact, 49 ALA. L. REV. 993 (1998) (detailing the differing needs of Alabama and Florida for clean water and of Georgia as a producer of pollution).

245. E.g., Port Authority of New York and New Jersey, N.J. STAT. ANN. § 32:1-1 (West 1990 \& Supp. 2001); N.Y. UNCONSOL. LAW §§ 6401-6423 (McKinney 2000).

246. See, e.g., Interstate Insurance Receivership Compact, 45 ILL. COMP. STAT. 160 (2000); Mich. COMP. LAWS ANN. $\$ 550.11$ (West 2001); NEB. REV. STAT. § 44-6501 (1998); WIS. STAT. 
compacts increased during the twentieth century, and a greater number and more varieties (including interstate agreements that do not result in formal legal compacts) are likely in the coming years. ${ }^{247}$

Attention to such agreements opens up possibilities for legislative innovation. For example, why assume that a new cause of action for VAWA victims could only exist in a state or a federal court? State court systems might coordinate their responses to victims of gender-based violence, as they already coordinate the movement and transfer of prisoners, ${ }^{248}$ and as they have begun to do in response to certain kinds of multistate actions such as mass torts and consumer products litigation. Further, in an array of such aggregate litigations (including a school desegregation case in Baltimore, asbestos claims in New York, and environmental injuries in Alaska), state and federal judges have crossed jurisdictional lines to respond to shared problems. ${ }^{249}$ A comparable joint venture, drawing on state courts' claimed advantages from working directly with families in disarray and on federal courts' association with equality law, could be forged to address violence against women.

In addition to prompting invention, awareness of interstate compacts and judicial joint ventures ought to prompt sustained investigation into the allocation of power within such agreements. ${ }^{250}$ Who has decisionmaking power? What patronage arrangements are facilitated? Should law and policy create incentives for or strictures on making such accords? ${ }^{251}$ For example, should multistate agreements be channeled through the compact model, requiring congressional approval, or ought we be supportive of more

ANN. § 601.59 (West 2000) (involving Illinois, Michigan, Nebraska, and Wisconsin, and addressing issues of insolvency of insurance companies).

247. See, e.g., Spiro, supra note 221 , at 590-95 (discussing the possibility of states entering into compacts or other agreements to adhere to international human rights provisions).

248. See Interstate Agreement on Detainers Act, 18 U.S.C. app. \$§ 1-9 (1994).

249. See William W Schwarzer, Nancy E. Weiss \& Alan Hirsch, Judicial Federalism in Action: Coordination of Litigation in State and Federal Courts, 78 VA. L. REV. 1689 (1992); JUdicial CONFERENCE of THE U.S., LONG RANGE PLAN FOR THE FEDERAL COURTS (1995), reprinted in 166 F.R.D. 53, $81-99$ (1995) (including a chapter entitled "Judicial Federalism"). In addition, a newsletter entitled The State-Federal Judicial Observer, published from 1993 to 1998 by the Federal Judicial Center and the National Center for State Courts, discussed these and other efforts. See The State-Federal Judicial Observer, http://www.fjc.gov/newweb/jnetweb.nsf/ pages $/ 178$ (last visited Nov. 27, 2001).

250. See, e.g., U.S. Steel Corp. v. Multistate Tax Comm'n, 434 U.S. 452, 459-71 (1978) (discussing both the history and the Court's interpretation of the respective roles of the states and that of the Congress in compacts); id. at 479-83 (White, J., dissenting) (same); Christi Davis \& Douglas M. Branson, Interstate Compacts in Commerce and Industry: A Proposal for "Common Markets Among States," 23 VT. L. REV. 133 (1998) (proposing three regions of the country in which states should develop regulations of securities and corporations to reduce trade barriers); Felix Frankfurter \& James M. Landis, The Compact Clause of the Constitution-A Study in Interstate Adjustments, 34 YALE L.J. 685 (1925) (calling for expanded attention to compacts and discussing the development of their use in relation to regional hydraulic energy supply).

251. See, e.g., Hess v. Port Auth. Trans-Hudson Corp., 513 U.S. 30, 34-38 (1994) (denying Eleventh Amendment immunity to the Port Authority Trans-Hudson Corporation (PATH), a bistate body operating transportation systems in New York and New Jersey). 
diverse and less formal forms of such contracts? Should legal rules, such as the presumptive longevity of interstate compacts and the current formal barriers to joint venturing by state and federal judges, be restructured? Compacts could be conceived either as threats to the intelligibility of states or as a kind of "morphing" of states, in issue-specific arenas, to take into account subject matters that do not track state boundaries. Responsive policymaking ought to depend on a thicker understanding of the degree to which formal compacts enhance the visibility and accountability of governing structures, as well as better empiricism on the frequency and form of noncompact multistate agreements. The central question is the degree to which compacts enhance or impede democratic goals identified with state-based federalism, including accountability and participation. ${ }^{252}$

Third, as joint and interactive decisionmaking becomes the subject of lawmaking, conflicts should be addressed under the rubric of preemption doctrine. Given that state and federal laws address aspects of family law or international relations, the issues become narrowed to whether, in a particular circumstance, legal regimes can cohabit and whether one set of rules needs to be set aside. These focused inquiries would require judges to retreat from their forays into global political theory and thin historicizing. Instead, they would have to detail how and why joint governance was or was not possible in a specific context. Crosby, the Court's decision in the Massachusetts Burma case, is exemplary of this preferable, albeit more mundane and less powerful, role for judges, confined to discussion of the degree to which redundant or overlapping governance can be tolerated in a particular instance. That such decisions do not etch clear lines for all further lawmaking becomes their virtue, as adjudication becomes appropriately "local" in the sense of being limited by legal rules applied to discrete factual circumstances. ${ }^{253}$ of course, preemption is not a magic bullet.

252. See, e.g., Jill Elaine Hasday, Interstate Compacts in a Democratic Society: The Problems of Permanency, 49 FLA. L. REV. 1, 8, 24-26 (1997) (identifying a "democratic tension" in compacts because, once they are approved by Congress, state governments are constrained in making changes and arguing that compact agencies are "remarkably unconcerned about popular needs and desires, even compared to state and federal agencies"). See generally JAMESON W. DOIG, EMPIRE ON THE HUDSON: ENTREPRENEURIAL VISIONS \& POLITICAL POWER AT THE PORT AUTHORITY (2001) (providing history and analysis of the development of that interstate system).

253. Whether state and federal power exists to incorporate international norms has spawned a good deal of debate. Compare Harold Hongju Koh, Transnational Public Law Litigation, 100 YALE L.J. 2347, 2350-71 (1991) (tracing the historical roots of federal common-law authority, the retrenchment in the name of comity, and the resurgence of a judicial role in enforcing international norms in domestic courts), with Curtis A. Bradley \& Jack L. Goldsmith, Customary International Law as Federal Common Law: A Critique of the Modern Position, 110 HARv. L. REV. 815 (1997) (disagreeing with Koh's view). Implicit in my approach is that federal courts have common-law-making powers, which could be exercised with deference to state courts. While the federal judiciary should not see itself as specially disabled to engage in law application, state courts can also serve as points of contact between international norms and domestic law. See generally Catherine Powell, Dialogic Federalism: Constitutional Possibilities for Incorporation 
Freewheeling Justices can impute intent to legislation and hence enhance their powers, ${ }^{254}$ but the methodology - examine statutes, apply facts, presume concurrency - cabins the reach of even the adventuresome.

Fourth, in addition to looking within the United States to survey and to analyze the range of federalism here, multi-faceted federalism may draw on lessons from abroad. The challenges of coexisting and coextensive legal regimes are common to all federations, which must address when to permit shared "competence" and when to require preemption. ${ }^{255}$ While one cannot transport one federation's solution to another, countries can learn of the plausibility of particular delineations of authority. Take, for example, the increasing and formalized position of NGOs in the United Nations, which permits these nongovernmental groups to have a place in some official meetings. ${ }^{256}$ In 1948, 41 NGOs played an official consultative role; in 1993, $978 \mathrm{did}$ so. ${ }^{257}$ Scholars of NGOs argue that the increased prevalence of NGOs should prompt a revision of theories about how authority and power are exercised. ${ }^{258}$ What role NGOs play in the United States has been given

of Human Rights Law in the United States, 150 U. PA. L. REV. (forthcoming 2001) (exploring the legality of multiple venues for the domestic application of international human rights law).

254. See, e.g., Lorillard Tobacco Co. v. Reilly, 121 S. Ct. 2404, 2445 n.8 (2001) (Stevens, J., concurring in part, concurring in the judgment in part, and dissenting in part) (complaining that the majority's construction of the statute preempting state tobacco regulation was in tension with the same majority's concern in Lopez for deference to state lawmaking); Egelhoff v. Egelhoff, 121 S. Ct. 1322 (2001) (holding that ERISA preempts a state law providing revocation upon divorce of a designation of a spouse as a beneficiary of nonprobate assets); id. at 1326 (Breyer, J., joined by Stevens, J., dissenting) (arguing that state and federal laws related to insurance and pension benefits could coexist).

255. See David Halberstam, Comparative Federalism and the Issue of Commandeering, in THE FEDERAL VISION: LEGITIMACY AND LEVELS OF GOVERNANCE IN THE U.S. AND THE E.U. (Kalypso Nicolaidis \& Robert Howse eds., forthcoming 2001) (detailing "commandeering" practices of Germany and the European Union and contrasting them with an anticommandeering precept emerging in United States law, and arguing that overlap as well as distinctions exist); Gráinne de Búrca, Rcappraising Subsidiarity's Significance After Amsterdam (unpublished manuscript, on file with author). See generally David O'Keeffe, Exclusive, Concurrent, and Shared Competence, in THE GENERAL LAW OF E.C. EXTERNAL RELATIONS, supra note 6, at 179 (examining the doctrine and texts delineating the competency of member states and the EU).

256. See, e.g., William R. Pace \& Mark Thieroff, Participation of Non-Governmental organizations, in THE INTERNATIONAL CRIMINAL COURT: THE MAKING OF THE ROME STATUTE, supra note 207, at 391 (describing the coordinated work of the 236 accredited NGOs in the negotiations for that court).

257. General Review of Arrangements for Consultations with Non-Governmental Organizations: Report of the Secretary General, U.N. ESCOR, Open-Ended Working Group on the Review of Arrangements for Consultations with Non-Governmental Orgs., Ist Sess., Agenda Item 3, U.N. Doc. E/AC.70/1994/5 (1994); see also TWENTY-FIFTH UNITED NATIONAL ISSUES CONFERENCE, THE UNITED NATIONS SYSTEM AND NGOS: NEW RELATIONSHIPS FOR A NEW ERA (1994).

258. See John Boli, World Authority Structures and Legitimatization, in CONSTRUCTING WORLD CULTURE: INTERNATIONAL NONGOVERNMENTAL ORGANIZATIONS SINCE 1995, supra note 184, at 267 (analyzing the relationships between international NGOs and nations, ranging from those working autonomously to those that work collaterally to those that "penetrate" and alter state power). See generally Dinah Shelton, The Participation of NGOs in International Judicial Proceedings, 88 AM. J. INT'L L. 611 (1994) (focusing on NGOs taking on the role of amici curiae in four permanent international courts). 
less attention. For example, might the National Association of Attorneys General be understood as an NGO, representing segments of state interests distinct from those presented through senators and members of Congress? Should the work of a host of such organizations become a part of political policymaking through formalized roles? What are the positive and the perverse effects of commingling or disaggregating the idea of "state interests" and states' decisional authority? ? $^{259}$ In short, once willing to let go of categorical federalism's strictures, opportunities for invention multiply. The options are great because political practitioners are engaging in a range of group-based actions, enlisting the local, state-level, national, and transnational, the governmental and the nongovernmental, and whatever other entities they can, all to bring them closer to whatever their aspirations may be.

Fifth, multi-faceted federalism makes more difficult the valorization of certain levels of government as specially able to get any particular social policy "right." Take the claim that the "national" is a venue committed to civil rights and that the federal courts are specially able to implement such commitments. Relying on the symbolic capital of a link between national lawmaking and civil rights, VAWA proponents argued that it was a traditional function of the national government to protect equality and to do so by vesting federal judges with jurisdiction. ${ }^{260}$ But that "tradition" was painfully incomplete when the country was founded, invigorated after the Civil War, then dismantled, then renewed, and now called again into question. The identity of the federal courts has shifted during the twentieth century-at times courts have been seen to be institutions of oppression (by labor and other populists) and at other times perceived to be institutions of salvation (by civil rights claimants). Both state and national constitutions speak of their commitments to equality, as do many other countries' constitutions and many international declarations. But to embody equality requires recommitment of national law in that direction, not simply the

259. The litigation of New York v. United States, 505 U.S. 144 (1992), provides an example. The statute at issue, on disposal of nuclear waste, had been enacted at the behest of the national organization of state governors, who had drafted and lobbied for its passage. Subsequent political problems within New York made difficult compliance with rules on locating disposal sites for low-level nuclear waste and entering into compacts with other states to do so. See id. at 154. One state's complaint was thus able to enlist the Supreme Court in undoing a bargained-for legal regime, as discussed in Justice Stevens's dissent. Id. at 213 (Stevens, J., dissenting). Missed there, as it was in Morrison, was the opportunity to develop doctrine on whether federal courts ought to be more reluctant to act in the name of federalism when congressional action is based on demands from specific kinds of state actors representing a majority of states.

260. See, e.g., Brief for the United States at 23, United States v. Morrison, 523 U.S. 598 (2000) (Nos. 95-5, 99-29), 1999 WL 1037259 
invocation of the nation as if it has intrinsically and inevitably allied itself with practices of equality. ${ }^{261}$

To equate the "local" with progressive human rights movements would also be erroneous. Above, I discussed a series of local innovationsfocused on forced labor, land mines, apartheid, and women's rightscheerfully allied with transnational human rights movements. But another group of local activities in the United States stands in opposition to such efforts and has been the brunt of targeted criticism from abroad. For example, the "local" in the United States has insisted on its right to execute individuals, juveniles included, despite transnational efforts to ban capital punishment. ${ }^{262}$ The phrase "states' rights" has been a shorthand for hostility to African Americans. Localities have also enacted ordinances aimed at limiting rights of lesbians and gays and of immigrants. In short, multi-faceted federalism counsels against assuming that either "the national" or "the local" has an intrinsically rosy glow.

In parallel fashion, while CEDAW has been discussed as a powerful example of the possibilities of transnationalism to improve gender relations, neither transnational lawmaking nor globalism is necessarily an engine of equality. Indeed, some current expressions of globalization do significant harm to women. An oft-cited example is that offshore manufacturing is made attractive by the unending supply of impoverished female workforces, seeking to survive through a range of underpaid jobs. ${ }^{263} \mathrm{I}$ claim no essence for globalization but only its existence, in that physical distances which had previously precluded certain forms of interactions no longer serve that function. What globalization-under current market and political conditions-has done is promote interest in forms of governance that regulate transactions outside and beyond the nation-state. That interest, in turn, has generated new opportunities for women to advance equality claims. Equality is not a necessary outcome of federating, but with the formulations of new structures come opportunities for alternative allocation of power. Gaps in governance are spaces in which all power-seekers, be

261. A parallel critique challenges the assumption that the "national" will be receptive to international human rights norms. See, e.g., Thomas M. Franck, Dr. Pangloss Meets the Grinch: A Pessimistic Comment on Harold Koh's Optimism, 35 Hous. L. Rev. 683 (1998).

262. See Spiro, supra note 221, at 571-72 (arguing that states are frequent violators of human rights, with examples of police brutality, prison conditions, and the death penalty). See generally Breard v. Greene, 523 U.S. 371 (1998) (declining to stop a state execution challenged on grounds of violation of international law because of procedural default on the claim).

263. Cf. Saskia Sassen, Toward a Feminist Analytics of the Global Economy, 4 IND. J. GLOBAL LEGAL STUD. 7, 27-28 (1996) (arguing that transnational migrations may be a means by which women gain authority, both within households and beyond, and hence that some global trends have empowered certain groups of women). See generally CHRISTA WICHTERICH, THE GLOBALIZED WOMAN 1-33 (Patrick Camiller trans., Zed Books 2d ed. 2000) (1998) (arguing the economic injuries that flow from globalization). The complexity of globalization for women is also examined in Carla Freeman, Is Local:Global as Feminine:Masculine? Rethinking the Gender of Globalization, 26 SIGNS 1007 (2001). 
they entrenched or newly fabricated, try to gain toeholds. And in this era, women's rights and human rights advocates have prompted governance institutions to make statements of commitment to equal treatment. ${ }^{264}$

That women have windows of opportunity to participate in generating laws does not necessarily result in laws good for all women. Serious questions, constant within feminism, remain about how to shape such equality demands and about which women will benefit. ${ }^{265}$ The category "women"-like the others discussed herein-is neither unitary nor necessarily permanent. Indeed, proponents of many forms of affirmative action deploy categories of identity in the hope of their future incoherence. Further, provisions that may benefit one group of women may not serve others of differing classes and races. The debates about the enactment of VAWA addressed such concerns. ${ }^{266}$ Transnational rights advanced in the name of women must also be interrogated to understand how their applications vary. ${ }^{267}$

Moreover, words about equality committed to paper in transnational documents such as CEDAW do not necessarily translate into conditions of equality in the lives of women and men. ${ }^{268}$ For example, some of the 165 countries that have ratified CEDAW have conditions oppressive to women more detrimental than those in the United States, a country that has not ratified CEDAW. Further, even when countries ratified CEDAW, they did so with unusually high numbers of reservations. ${ }^{269}$ In addition, CEDAW has

264. See Helen Durham, Women and Civil Society: NGOs and International Criminal Law, in 3 WOMEN AND INTERNATIONAL HUMAN RIGHTS LAW, supra note 191, at 819 (2001).

265. See, e.g., Bob Reinalda, Dea Ex Machina or the Interplay Between National and International Policymaking: A Critical Analysis of Women in the European Union, in SEX EQUALITY POLICY IN WESTERN EUROPE, supra note 194, at 197 (analyzing the inability to move beyond formal gender equality models).

266. Kimberlé Crenshaw, Mapping the Margins: Intersectionality, Identity Politics, and Violence Against Women of Color, 43 STAN. L. REV. 1241 (1991); Rivera, supra note 92, at 491509.

267. For example, what gender meant was a point of contention in the framing of provisions of the International Criminal Court. According to Steains, the text leaves open the possibility of inclusion of sexual orientation as a form of impermissible persecution but does not so specify because some states would not agree to that express prohibition. Steains, supra note 207, at 370 74.

268. See, e.g., John Valery White \& Christopher L. Blakesley, Women or Rights: How Should Women's Rights Be Conceived and lmplemented?, in 2 WOMEN AND INTERNATIONAL HUMAN RIGHTS LAW, supra note 191, at 51 (2000) (registering disappointment at enforcement of women's rights and advocating better standards for implementation of CEDAW); see also NUSSBAUM, supra note 182, at 24-31 (discussing India's "very woman-friendly" constitution but a "reality" of great inequality, citing examples including rape, child marriage, child labor, and violence).

269. Press Briefing on Optional Protocol to Convention on Elimination of All Forms of Discrimination Against Women (Dec. 10, 1999) (on file with author); see also Hilary Charlesworth, Christine Chinkin \& Shelly Wright, Feminist Approaches to Intemational Law, 85 AM. J. INT'L L. 613, 631-33 (1991) (discussing the significance of those reservations); William A. Schabas, Reservations to the Convention on the Elimination of All Forms of Discrimination Against Women and the Convention on the Rights of the Child, 3 WM. \& MARY J. WOMEN \& L. 
limited means of implementation. ${ }^{270}$ CEDAW constitutes an achievement of significant legal and political proportions, but its translation into practice has not fully materialized. ${ }^{271}$ Similarly, I make no claim that international organizations are particularly receptive to women's rights; indeed, some are notoriously poor places for women to work. ${ }^{272}$ Nor are NGOs a glorious alternative, as they often not only reflect gendered allocations of work and authority but risk reinscribing them. ${ }^{273}$

79 (1997) (detailing the reservations to both treaties and the problems that such reservations entail).

270. One mechanism is a state-to-state complaint, brought to the International Court of Justice. Another is a system of reports, in which member states take on the obligation to study and report on their own implementation effors. A committee, comprised of twenty-three members, receives the reports and then engages in an exchange with the reporting state about the achievements and problems. Convention on the Elimination of All Forms of Discrimination Against Women, supra note 167 , arts. 17, 18, 1249 U.N.T.S. 21, 22; see also ASSESSING THE STATUS OF WOMEN, supra note 218. The Committee's limited staff and significant workload is detailed by member Dame Silvia Cartwright in The Committee on the Elimination of Discrimination Against Women, in 2 WOMEN AND INTERNATIONAL HUMAN RIGHTS, supra note 191, at 165-81 (2000). Some states that have signed CEDAW had not, as of 1998, filed reports; others have provided stale information. Valerie A. Dormady, Status of the Convention on the Elimination of All Forms of Discrimination Against Women (CEDAW) in 1998, 33 INT'L LAW. 637 (1999).

A third implementation mechanism is of more recent vintage and as of this writing has yet to be used. By December 2000, a sufficient number of countries had ratified an "optional protocol" to bring into effect the provision that, after exhausting available intemal remedies, women may bring complaints directly to the CEDAW committee. Optional Protocol to the Convention on the Elimination of All Forms of Discrimination Against Women, U.N. GAOR, 54th Sess., Agenda Item 109, U.N. Doc. A/RES/54/4 (1999). See also Women's Charges To Be Heard Now in U.N., N.Y. TIMES, Dec. 22, 2000, at A13; U.N. DEP'T OF ECON. \& SOC. AFFaIRS, ThE CONVENTION ON THE ELIMINATION OF ALL FORMS OF DISCRIMINATION AGAINST WOMEN: THE OPTIONAL Protocol: TEXT AND MATERIALS 1-2, 6-7, 110-18, U.N. Sales No. E.00.IV.2 (2000) (detailing the process and also stating in Article 17 that any member state signing this protocol may not impose reservations).

271. Testing the effects of CEDAW requires a metric; for example, some argue that CEDAW has empowered NGOs concemed with women's rights in their work both transnationally and within countries. See Afsharipour, supra note 208, at 146-70 (discussing noncompliance while maintaining optimism about the progress made through pressure from women's NGOs).

272. See Inglis, supra note 208, at 114-18 (describing the "extreme gender imbalance in positions of power" in the United Nations); Charlesworth et al., supra note 269, at 622-30 (detailing such problems in United Nations-based activities, as well as the normative structures of international law that make equality work difficult).

273. See Sabine Lang, The NGOization of Feminism: Institutionalization and Institution Building Within the German Women's Movements, in TRANSITIONS, ENVIRONMENTS, AND TRANSLATIONS: Feminisms IN INTERNATIONAL POLITICS 101, 116 (Joan W. Scott, Cora Kaplan \& Debra Keates eds., 1997) (describing the use of NGOs to channel women into "local contexts, the tertiary sector, and the feminist social service and job market," putting them at the margins of political decisionmaking); Deborah Mindry, Nongovernmental Organizations, "Grassroots," and the Politics of Virtue, 26 SIGNS 1187 (2001) (examining NGO work in South Africa and finding both transformation of traditional gender and racial politics as well as enduring residues of colonialism). See generally FEMINISTS DOING DEVELOPMENT (Marilyn Porter \& Ellen Judd eds., 1999) (providing case studies of efforts to enhance women's economic wherewithal); BishWAPRIYA Sanyal, CoOperative Autonomy: The Dialectic OF State-NGOS RELATIONSHIP IN DEVELOPING COUNTRIES (Int'l Inst. for Labour Studies, Research Series No. 100,1994 ) (analyzing the multiple relationships between NGOs and states and the structural attributes of effective NGOs). 
Rather, globalism offers a contested political space, an interesting, additional place of potential power, of shifting categories and of new organizations. Proponents of women's rights have had the occasion to work in that venue and have been able to bring attention to injuries and their sources that heretofore were not of great interest to international institutions. A contemporary account can properly point to the correlation between expressions of human rights and certain transnational efforts made possible by historically specific conditions but ought not to lapse into essentializing any level of governance as intrinsically a source of equality norms.

Moving toward a multi-faceted approach thus requires a willingness to face such complexities. The nation-state has been the means of governance for some three centuries, and for each harm that form of government has generated, a benefit can also be detailed. The perceived desirability of shifts that diminish the import of the nation as the key unit of governance depends in part on empirical assessments resting inevitably on debatable databases and a host of unknowns. If the nation no longer serves as a unit of accountability, if (for example) within the United States the "one voice" doctrine of international law relaxes, will a larger role for regions and localities do harm to the political stability of the United States and whatever human rights agendas it espouses? Might categorical federalism be a better route to import evolving equality norms into United States jurisprudence, based on an understanding that international law is itself a part of national law and therefore could preempt divergent state practices? ${ }^{274}$ Are international human rights obligations assigned at the national level at risk if localities gain prominence and the reliance on national borders diminishes?

These questions are not, of course, novel or unique to the United States. Every federation is an ongoing experiment in how to maintain accountability and distinctive agendas concurrent with the reduction of the saliency of borders. ${ }^{275}$ While at one time, physical power and physical space provided at least temporizing answers that made plausible that unity of power (democratic or not), those boundaries no longer have the capacity to contain. ${ }^{276}$

274. This is an approach suggested by Harold Koh. See Koh, Bringing International Law Home, supra note 9.

275. See DE BÚRCA, supra note 6 (addressing this issue in the context of the European Union); de Búrca, supra note 255 (arguing that the legal formulation of exclusive competence in the EU system is not helpful because it addresses only two levels of authority-the European Community and the Member State-and because it relies on efficiency over other criteria for determining the proper level of decisionmaking).

276. JEAN-MARIE GúthenNo, THE END OF THE NATION-State (Victoria Elliott trans., Univ. of Minn. Press 1995) (1993). 
The argument is not that place is irrelevant. The local is very much present in each person's life, manifested by the persons with whom one forms families and communities, by the weather systems that shape daily routines, and by the regions that are proximate and offer either friendship or hostility. But the boundaries of a given nation no longer control markets and can no longer promise physical security. In a parallel fashion, the family unit (predicated on very undemocratic power) once controlled goods, services, and people. The revolt against patriarchal families also ruptures the ability to confine familiar relationships to only certain kinds of pairings and offspring. The litigation about the civil remedy in VAWA raised an enduring problem of United States constitutional law about how to divide the power of judgment between courts and legislatures and, to a lesser extent, between states and Congress. The majority sought to answer by turning back to old images of state boundaries and to worn equations of jurisdiction and gender. The assumptions that located certain forms of action in the nation and other forms of action in local institutions have been overtaken by the permeability of institutions, both large scale political and small scale familial. Therefore, a retreat to those categories becomes a willed but unsuccessful effort to buffer oneself and one's country from the transformations with which one has to live.

One cannot essentialize particular forms of federated governance as guarantees of certain outcomes or particular kinds of family relationships as generative of human growth. In the end, neither categorical nor multifaceted federalism provides solutions to the problem of democratic organization and accountability. These are but the forms that may, depending on the content and meaning humans import to them, serve such ends. 